\title{
Article \\ Diverse Effect of Two Cytokinins, Kinetin and Benzyladenine, on Plant Development, Biotic Stress Tolerance, and Gene Expression
}

\author{
Zoltán Bozsó and Balázs Barna *
}

check for updates

Citation: Bozsó, Z.; Barna, B. Diverse Effect of Two Cytokinins, Kinetin and Benzyladenine, on Plant Development, Biotic Stress Tolerance, and Gene Expression. Life 2021, 11, 1404. https://doi.org/10.3390/ life11121404

Academic Editor: Francois Lefort

Received: 22 November 2021 Accepted: 11 December 2021 Published: 15 December 2021

Publisher's Note: MDPI stays neutral with regard to jurisdictional claims in published maps and institutional affiliations.

Copyright: (c) 2021 by the authors. Licensee MDPI, Basel, Switzerland. This article is an open access article distributed under the terms and conditions of the Creative Commons Attribution (CC BY) license (https:// creativecommons.org/licenses/by/ $4.0 /)$.
Centre for Agricultural Research, ELKH, Plant Protection Institute, Herman Ottó Str. 15, H-1022 Budapest, Hungary; bozso.zoltan@atk.hu

* Correspondence: barna.balazs@atk.hu

\begin{abstract}
The plant hormones cytokinins affect a various array of plant growth and development processes as well as responses to biotic and abiotic stresses. In this study, the opposite effect of two different cytokinins kinetin ( $\mathrm{N}^{6}$-furfuryladenine) and benzyladenine (BA) on development and on the tolerance of Arabidopsis and tobacco plants to virus, bacteria, and fungi infection was reported. Treatments of Arabidopsis and tobacco seedlings with saturated solutions of BA inhibited plant progress, while treatments with saturated water solution of kinetin promoted plant development. Furthermore, BA pre-treatments strongly reduced the number of TMV (Tobacco mosaic virus) lesions on tobacco and the tissue damage caused by the incompatible Pseudomonas bacteria on Arabidopsis and tobacco leaves. Similarly, BA pre-treatment significantly reduced the necrotic disease symptoms of Botrytis cinerea infection. Kinetin pre-treatments had a much weaker or no protective effect on the damage caused by the above pathogens. Accordingly, Arabidopsis gene expression profiles after treatments also showed that the two cytokinins have different effects on several plant processes. The gene expression results supported the more robust effect of BA, which up and downregulated more than 2000 genes, while only 436 genes were influenced by kinetin treatment. It is noteworthy that BA and kinetin treatment changed gene expressions in the same direction only in a relatively few cases (73 upregulated and 70 downregulated genes), and even 28 genes were regulated into the opposite directions by BA and kinetin. Both treatments had a strong effect on auxin and gibberellinrelated genes, but only BA had a significant effect on cytokinin-induced processes. While kinetin exclusively activated the flavonoid synthesis genes, BA affected more significantly protein synthesis, photosynthesis, and plant defence-related genes. In conclusion, BA solution had sometimes the opposite and generally a much stronger effect than kinetin solution not only on the development and on biotic stress tolerance of tobacco and Arabidopsis plants but also on the gene expressions. The stronger protective effect of BA to necrotic stresses is probably due to its stronger senescence inhibitory effect on plant tissues, as supported by the stronger chlorophyll retardation of the BAtreated leaves.
\end{abstract}

Keywords: benzyladenine; kinetin; Arabidopsis; tobacco; Tobacco mosaic virus; Pseudomonas syringae; Botrytis cinerea; gene expression changes; chlorophyll content

\section{Introduction}

Although much is known about cytokinins, still, many important open questions remain. Since in preliminary experiments, we found that kinetin and benzyladenine pretreatments have different effects on the development of Arabidopsis plants, our aim was to compare the effect of these two cytokinins on Arabidopsis and tobacco plants under the same conditions.

Cytokinins are a class of plant hormones that promote cell division, plant growth, and plant development, in addition to responses to abiotic and biotic stresses. Moreover, cytokinins have been shown to slow the senescence of plants and assembling nutrients 
from nearby tissues [1-4]. Furthermore, cytokinins are signalling molecules acting both locally and at a distance $[5,6]$. The first cytokinin to be identified was kinetin as a degradation product of DNA that promotes plant cell division. Evidence for the presence of kinetin in natural products has been provided by mass spectrometric analysis of DNA components [7]. Both benzyladenine and kinetin are adenine-type cytokinins with a similar chemical structure, but in BA, a benzyl group can be found instead of the furfuryl group. It is noteworthy that senescence was delayed by kinetin and BA in an oat leaf test, but not by natural cytokinins, zeatin, and isopentenyl adenine [8]. In addition, both benzyladenine and kinetin show antioxidant properties in human skin fibroblast and in mammalian cells $[9,10]$.

Elevated cytokinin and auxin content has a pivotal role in keeping juvenility and the active metabolism of plant tissue infected by biotrophs, such as rust or powdery mildew (green island syndrome), and in directing nutrient transport to the infected plant parts. On the other hand, it has been known for a long time that the senescence or juvenility of plant tissues has a strong effect on their reactions to abiotic stresses and pathogen attacks [11]. Generally, necrotrophic pathogens prefer senescent tissues, but biotrophic pathogens prefer juvenile tissues, while hemibiotrophic pathogens such as Pseudomonas bacteria or Phytothora infestans are in some respect in between [12,13]. Accordingly, any type of inhibition of plant senescence, such as treatment with cytokinins or transformation with cytokinin biosynthesis genes shall improve the resistance of plants to necrosis-inducing necrotrophic pathogens such as Botrytis cinerea or Sclerotinia ssp., but it shall increase susceptibility to biotrophic pathogens such as powdery mildew or rust [14]. In addition, many studies demonstrate that a number of senescence-associated transcription factors (Sen-TFs) function as positive or negative regulators of plant immunity [11,13].

Although in the past decades, significant progress has been made in the understanding of the molecular mechanisms of plant disease resistance, still, there are many open questions [11,15-17]. This statement is also valid regarding the role of plant hormones and especially of cytokinins in plant immunity [18-20]. In Arabidopsis, it was suggested that cytokinin-mediated resistance functions through SA-dependent mechanisms based on the finding that ARR2 (a positive regulator of cytokinin signalling) interacts with TGA3 (a transcription factor involved in inducing SA-responsive genes) in the regulation of the disease marker gene PR1 against biotrophic infections in plants [18]. Furthermore, cytokinin overexpressing transgenic plants and exogenous cytokinins feeding approaches unanimously resulted in "more cytokinins less disease symptoms" and vice versa [21] Similarly, we also found that cytokinin overproduction induced the juvenility of plant tissues correlated with augmented antioxidant activities, and it is connected to elevated tolerance to necrotic symptoms caused by pathogens [14,22-24].

Here, we report on the diverse, sometimes opposite effect of the two cytokinins, kinetin and benzyladenine, on Arabidopsis and tobacco plant development, chlorophyll content of senescent leaves, and their tolerance to virus, bacteria, and fungi, in addition to the effect on gene expressions.

\section{Materials and Methods}

\subsection{Plant Materials and Pathogens}

Experiments were carried out with the wild-type Columbia ecotype of Arabidopsis thaliana (L.) Heynh, and Nicotiana tabacum L. cv. Xanthi-nc carrying the hypersensitive $N$ resistance gene to TMV. Seeds of Arabidopsis plants were sown into pots and kept 2 days at $5{ }^{\circ} \mathrm{C}$ in dark; then, they were put into a growth chamber for an $11 \mathrm{~h}$ photoperiod light $/ 13 \mathrm{~h}$ dark, $140 \mu \mathrm{mol} \mathrm{m}^{-2} \mathrm{~s}^{-1}$ fluorescent lightening. Tobacco plants were grown under standard greenhouse conditions $\left(18-23^{\circ} \mathrm{C}\right.$; about $16 \mathrm{~h}$ daylight with $160 \mu \mathrm{mol} \mathrm{m}^{-2} \mathrm{~s}^{-1}$ supplemental light for $8 \mathrm{~h}$ per day; relative humidity: $75-80 \%$ ).

Tobacco leaves were inoculated with a suspension of the U1 strain of Tobacco mosaic virus (TMV) as described earlier [25]. Briefly, the virus was maintained in N. tabacum cv. Samsun plants carrying no $N$ resistance gene, and leaves showing typical symptoms of 
TMV infection were ground ( $1 \mathrm{~g}$ in $10 \mathrm{~mL}$ of $10 \mathrm{mM}$ sodium phosphate buffer, $\mathrm{pH} 7.0$ ) in a mortar, and the homogenate was used for inoculation.

Two strains of the hemibiotrophic Pseudomonas bacteria were used: P. syringae pv. syringae 61 (P.s. pv. s. 61 [26]) and P. syringae pv. tomato strain DC3000 (P.s. pv. t. DC3000 [27]). P.s. pv. s. 61 elicits the hypersensitive response (HR) in non-host plants. P.s. pv. t. DC3000 is the cause of bacterial speck disease on tomato and Arabidopsis, and it gives a compatible reaction on Columbia ecotype. Bacterial cultures were maintained on nutrient agar at $30^{\circ} \mathrm{C}$. Cultures were transferred to fresh medium 16 to $24 \mathrm{~h}$ prior to use. For infection, all fully developed plant leaves were brushed either with water (control) or with bacterial suspension $\left(10^{8} \mathrm{cfu} \mathrm{cm}^{-3}\right)$ [28]. In the case of tobacco, in addition to incompatible P. s. pv. s. 61, suspensions of the compatible P.s. pv. tabaci (P.s. pv. tabaci, NCAIM1 B.01601-National Collection of Agricultural and Industrial Microorganisms, Budapest, Hungary) bacteria were injected into the leaves and evaluated by scoring (from 0 to 4 ) the necrotic damage caused by bacterial suspensions injected into tobacco leaves 3 days post inoculation.

As a necrotrophic pathogen, Botrytis cinerea strain b05.10 [29] was used. Infection was carried out on leaves derived from 50-55-day-old tobacco plants treated with $10 \mathrm{~mL}$ water, BA, or kinetin solutions for 14 days. The leaves were placed on wet filter papers in glass Petri dishes ( $28 \mathrm{~cm}$ in diameter) and inoculated with 0.5 diameter agar discs from Botrytis cinerea 5-day-old culture. Evaluation of the symptoms was carried out by measuring lesion development on the leaves. The significance of the difference between two values of disease damage was evaluated by $t$-test.

\subsection{Experimental Design and Chlorophyll Content Determination}

Saturated water solutions of kinetin $(0.349 \mathrm{mM})$ or BA $(0.266 \mathrm{mM})$ were used for treatments throughout the experiments. Older and younger Arabidopsis and tobacco plants were used to examine the effect of the two cytokinins on plants of different ages. For Arabidopsis treatments, either plant leaves that were 45-50 days old were brushed with the solutions, or Arabidopsis plants that were 30-35 days old were sprinkled with $5 \mathrm{~mL}$ solution to the root every day for 14 days. In the case of tobacco at an early seedling stage (35-40 days old) or at a later stage (50-55 days old), plants were sprinkled with 5 or $10 \mathrm{~mL}$ solution respectively to the root for 10 days. Water-treated plants were used as controls.

In separate experiments, Xanthi tobacco plants that were 50-55 days old were sprinkled with saturated BA, saturated Kin, or water solutions in 3 groups. The first group of plants received $30 \mathrm{~mL}$ of cytokinin solutions only on the first day, the second group received theirs three days after the first doses had the second $30 \mathrm{~mL}$ (altogether $60 \mathrm{~mL}$ ) of cytokinin solutions, and the third group of plants again after 3 days received a third $30 \mathrm{~mL}$ (altogether $90 \mathrm{~mL}$ ) of test solutions.

Chlorophyll content was measured in the second fully developed leaves (from the soil level) of tobacco plants. Five weeks after the last treatment with the cytokinin solutions, chlorophyll was extracted with $80 \%$ acetone from tobacco leaves and determined at 647 and $660 \mathrm{~nm}$ as described earlier [30].

\subsection{RNA Purification}

For one RNA sample, approximately $100 \mathrm{mg}$ of leaf tissues were collected from three BA, kinetin, or water-treated plants at indicated times. The samples were frozen in liquid nitrogen and stored at $-70^{\circ} \mathrm{C}$. To obtain three independent biological replicates, sample collections were repeated with three plant generations. Total RNA was extracted from frozen tissues using Qiagen RNeasy Plant Mini kit and Qiagen Rnase-free Dnase Set (Qiagen, Germantown, MD, USA). RNA purity was determined through a Nanodrop ND1000 (NanoDrop Technologies Inc., Wilmington, DE, USA), and the integrity was checked by 2100 Bioanalyser (Agilent Technologies Inc., Santa Clara, CA, USA). 


\subsection{Microarray}

Agilent Arabidopsis (V4) Gene Expression Microarray, $4 \times 44 \mathrm{~K}$ Array (one glass slide formatted with four high-definition $44 \mathrm{~K}$ arrays) were used for gene expression detections.

Amplification and labelling were performed according to the Agilent protocol (TwoColor Microarray-Based Gene Expression Analysis Version 6.7). The method uses a T7 RNA Polymerase Blend, which simultaneously amplifies the target material and incorporates Cyanine 3-CTP or Cyanine 5-CTP.

The hybridization protocol was processed through a hybridization oven (Agilent Technologies Inc., Santa Clara, CA, USA). Then, a gasket slide (Agilent Technologies Inc., Santa Clara, CA, USA) was stuck on the microarray slide and then put it in to Agilent Microarray Hybridization Chamber (Agilent Technologies Inc., Santa Clara, CA, USA). The hybridization master mix solution was prepared with components from a Gene Expression Hybridization Kit (Agilent Technologies Inc., Santa Clara, CA, USA) and prepared according to the Agilent protocol. Hybridization solution samples were mixed and loaded onto the gasket slide surface. Then, the microarray slide was added on the top of the gasket slide. Three assembled slides chambers were placed in a rotisserie in a hybridization oven, and they were hybridized for $17 \mathrm{~h}$ at $65^{\circ} \mathrm{C}$. The hybridization rotator was set to rotate at $10 \times \mathrm{g}$. Post-hybridization washing was done using Gene Expression Wash Buffer Kits with increasing stringency (Agilent Technologies Inc., Santa Clara, CA, USA). Microarrays were scanned with InnoScan 900 (Innopsys, Carbonne, France) at a resolution of $5 \mu \mathrm{m}$. Grid files (gpr file) were created in Mapix software (Innopsys, Carbonne, France) through a microarray image file and a microarray layout file (.gal file). All data processing was performed using functions from package limma in R. We performed background correction by the method "normexp" [31] at first. As a second step, we performed within array normalization by the method "loess" [32-34], and then, we performed between array normalization by method "Aquantile" [35]. As a last step of data preprocessing, we replaced all groups of replicated probes by their average value. The differential expression was also computed with use of package limma, particularly by functions $\operatorname{lmFit}$, eBayes, and top Table.

\subsection{Primer Design and Quantitative RT-PCR Analysis of Gene Expression}

DNase-treated (TURBO DNA-free Kit, Thermofisher, Waltham, MA, USA) total RNA $(1.5 \mu \mathrm{g})$ was used for the synthesis of $20 \mu \mathrm{L}$ cDNA (High-Capacity cDNA Reverse Transcription Kit, Applied Biosystems) with random primers. Two and a half $\mu \mathrm{L}$ from a 10-fold dilution of cDNA stock was used in each $15 \mu \mathrm{L}$ reaction using a qPCRBIO SyGreen Mix Lo-ROX (PCR Biosystems, London, UK) real-time PCR mix. The final primer concentrations in $15 \mu \mathrm{L}$ PCR reaction were $0.3 \mu \mathrm{M}$. Real-time PCR amplifications were performed in a DNA Engine Opticon 2 thermocycler (MJ Research, Hercules, CA, USA). The cycling parameters were $95^{\circ} \mathrm{C}$ for $3 \mathrm{~min}$ followed by 40 cycles of $95^{\circ} \mathrm{C}$ for $10 \mathrm{~s}$ and $60{ }^{\circ} \mathrm{C}$ for $30 \mathrm{~s}$. Melting curve runs were also performed at the end of each PCR reaction to verify the presence of a single product. Measured $C(\mathrm{~T})$ values were normalized to the constitutive expressed ubiquitin-conjugating enzyme AT1G14400 C(T) values (forward primer: CTCTGTGACCCTAATCCGAATTCT; reverse primer: GCGCTTGCTTTCGCTGTAC). A total of 24 representative genes that showed significant expression changes in microarray experiments were used for qPCR validating measurements (Supplementary Table S2). The relative quantification of gene expression was carried out using the comparative cycle threshold $[\mathrm{C}(\mathrm{T})]$ method for the calculation of $\Delta \mathrm{C}(\mathrm{T})$ and $\Delta \Delta \mathrm{C}(\mathrm{T})$ values. Three biological replicates of treated (benzyladenine or kinetin) and untreated control samples were used for PCR, and the averages of the treated values were divided by the values of untreated values.

\section{Results}

\subsection{Benzyladenine and Kinetin Have Different Effects on Plant Development}

To compare the effects of BA and kinetin on plant phenotype, we treated plants with the two cytokines by various ways at different developmental stages of Arabidopsis and 
tobacco. Brushing of Arabidopsis leaves with BA solution inhibited the development of the flowering stem and induced thickening and curling of the central rosette leaves. In contrast, kinetin treatment rather promoted flowering, and no rosette leaf thickening or curling was observed (Figure 1A). In addition, when BA solution was sprinkled at an early developmental stage to the roots, the development of both Arabidopsis and tobacco plants was strongly inhibited, while a similar application of kinetin had no visible effect (Figure 1B,C). The application of BA solution to tobacco at later developmental stage by watering caused a rapid formation of small leaves close to the soil level (Figure 1D), while the same application of kinetin had no or weak effect (data not shown).
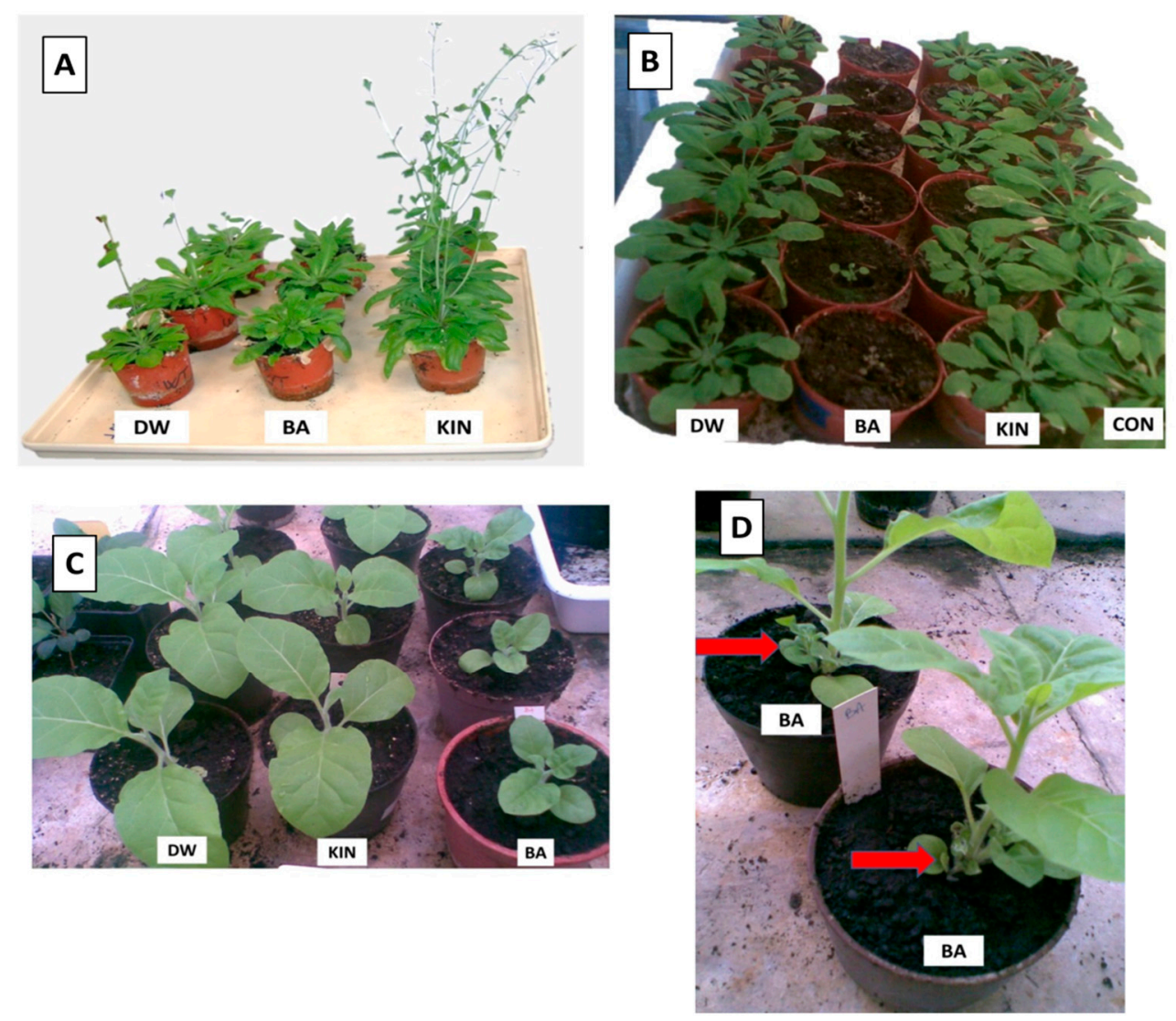

Figure 1. Effect of distilled water (DW), benzyladenine (BA), or kinetin (KIN) solutions on Arabidopsis $(\mathbf{A}, \mathbf{B})$ and tobacco $(\mathbf{C}, \mathbf{D})$ development. Plant leaves were brushed with the solutions for 14 days (A) or sprinkled with $5 \mathrm{~mL}$ solution to the root at early seedling $(\mathbf{B}, \mathbf{C})$ or with $10 \mathrm{~mL}$ solutions for 10 days at a later stage $(\mathbf{D})$. $\mathrm{CON}=$ non-treated control. On picture (D), the red arrows show the small leaves close to the soil level induced by BA treatment.

When older tobacco plants were treated with different doses of BA, it was observed that the effect of lower BA doses was weaker. Meanwhile, a $3 \times 30 \mathrm{~mL}$ dose of saturated BA solution strongly (Figure 1D), $2 \times 30 \mathrm{~mL}$ doses slightly, and the $1 \times 30 \mathrm{~mL}$ dose did not induce the rapid formation of small leaves close to the soil level. The effect of kinetin compared to BA was weaker because kinetin solution at $3 \times 30 \mathrm{~mL}$ dose caused a slight formation of small leaves at the soil level, while $2 \times 30 \mathrm{~mL}$ and $1 \times 30 \mathrm{~mL}$ doses caused no formation of small leaves at the soil level at all (data not shown).

Since we found that high doses of cytokinins were able to inhibit the senescence of older tobacco leaves, the chlorophyll content as a senescence marker of these leaves was determined. The chlorophyll content of the second fully developed leaves (from the ground) of tobacco plants showed correlation with the amount of the applied cytokinins (Figure 2). Compared with kinetin, BA was more efficient in the retardation of both chlorophyll a and 
b degradation, but the highest dose of kinetin $(3 \times 30 \mathrm{~mL})$ was more effective than the lowest doses of BA $(1 \times 30 \mathrm{~mL})$. The lowest dose of kinetin $(1 \times 30 \mathrm{~mL})$ had no inhibitory effect on chlorophyll degradation compared to control, water-treated tobacco leaves.

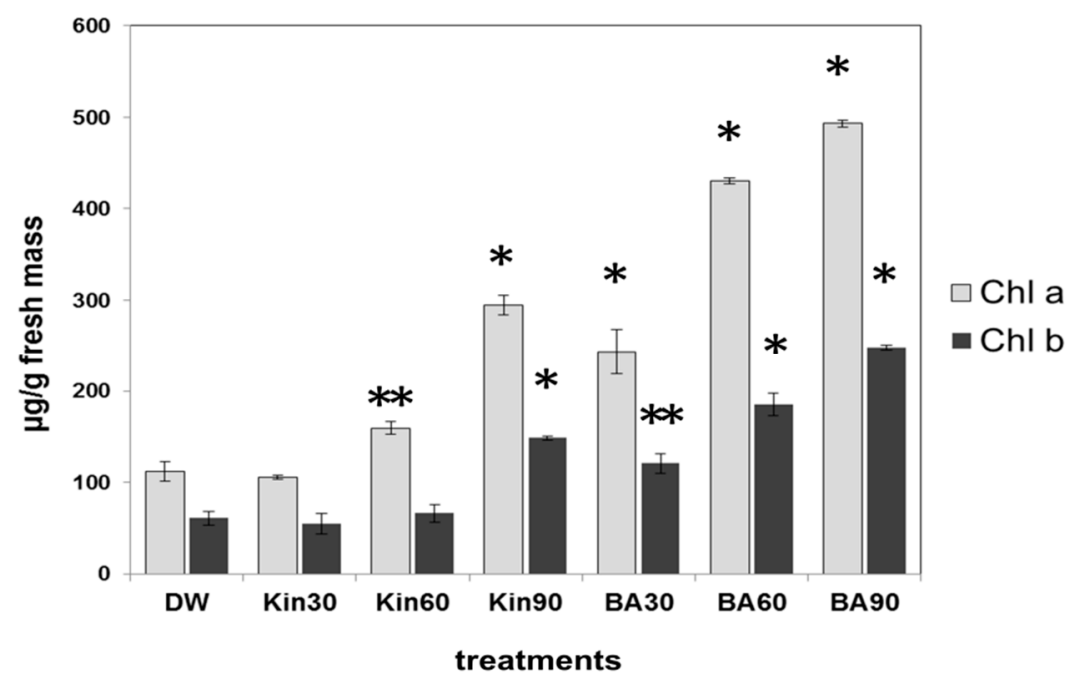

Figure 2. Chlorophyll $\mathrm{a}$ and $\mathrm{b}$ contents ( $\mu \mathrm{g} / \mathrm{g}$ fresh mass) of leaves from Xanthi tobacco plants pre-treated with distilled water $(\mathrm{DW}), 30 \mathrm{~mL}(1 \times 30), 60 \mathrm{~mL}(2 \times 30)$, or $90 \mathrm{~mL}(3 \times 30)$ of saturated benzyladenine (BA) or kinetin (KIN) solutions. Chlorophyll contents were determined five weeks after the last treatment with the cytokinin solutions. Bars represent mean \pm standard deviations of three replicates of a representative experiment from two independent experiments with similar results. The significant difference from the corresponding water-treated control was determined (* $p<0.005,{ }^{* *} p<0.05$, two-tailed $t$-test).

\subsection{Benzyladenine and Kinetin Have Different Effect on Biotic Stress Tolerance}

Pre-treatments with the BA or kinetin had a different effect on the reactions of plants to pathogen infections as well. Tobacco mosaic virus (TMV) induced necrotic lesions in the incompatible reactions on leaves of Nicotiana tabacum cv. Xanthi nc tobacco. The lesion number caused by TMV infection was strongly and significantly reduced both on lower or upper leaves as compared to water-treated leaves if tobacco plants were sprinkled every day for 10 days with BA solution before infection. On the other hand, pre-treatment with kinetin solution had a more slight effect on lesion number both on lower and upper leaves as compared to the control water-treated plants (Figure 3A).

Ion leakage correlates well with the membrane damage during necrosis development, and it is a good marker of cell damage; therefore, conductivity measurements were carried out as well. Similarly to lesion numbers, ion leakage from TMV-infected tobacco leaf discs was significantly reduced when the plants were pre-treated with BA as compared to water-treated controls, but no significant difference was found when tobacco plants were pre-treated with kinetin solution (Figure 3B). The effect of different doses of the two cytokinins on TMV-induced lesions on Xanthi tobacco leaves was also tested. We found that the higher the amount of BA or kinetin, the less the number of TMV-induced lesions. Again, BA had a stronger effect than kinetin, but the highest dose of kinetin was more effective at suppressing TMV lesions than the lowest dose of BA (Figure 4). 
A

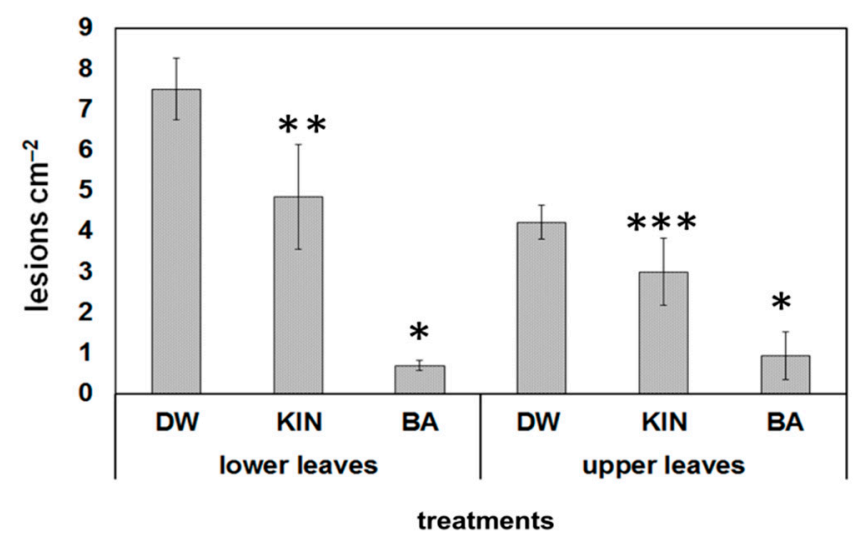

B

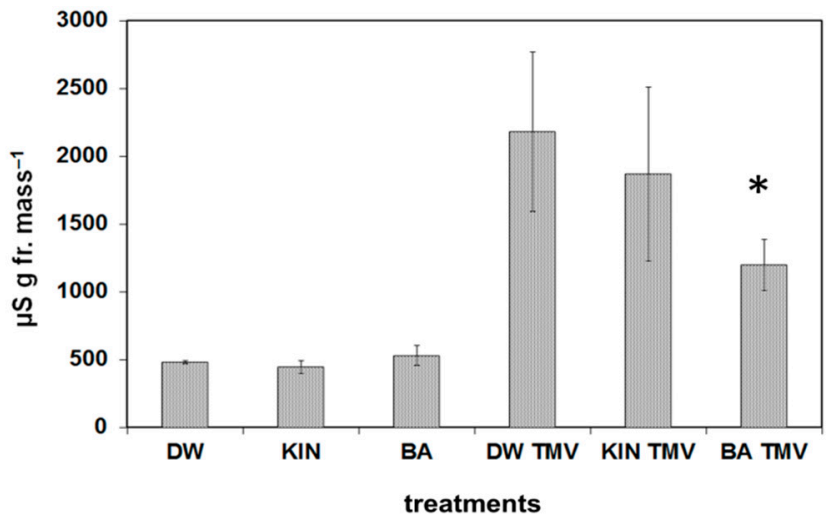

Figure 3. Effect of water (DW), kinetin (KIN), or benzyladenine (BA) pre-treatment on TMV infection on Xanthi nc. tobacco leaves. Infection was carried out 2 days after the last treatment. (A) Number of lesions on lower and upper TMV-infected leaves. ${ }^{*} p<0.001,{ }^{* *} p<0.05,{ }^{* * *} p<0.1$ two-tailed $t$-test. (B) Ion leakage from TMV-infected leaf discs of water (DW), kinetin (KIN), or benzyladenine (BA) pre-treated tobaccos. Bars represent the mean \pm standard deviations of three replicates of a representative experiment from three independent experiments with similar results. The significant difference from the corresponding water-treated control was determined $\left({ }^{*} p<0.05\right.$, two-tailed $t$-test).

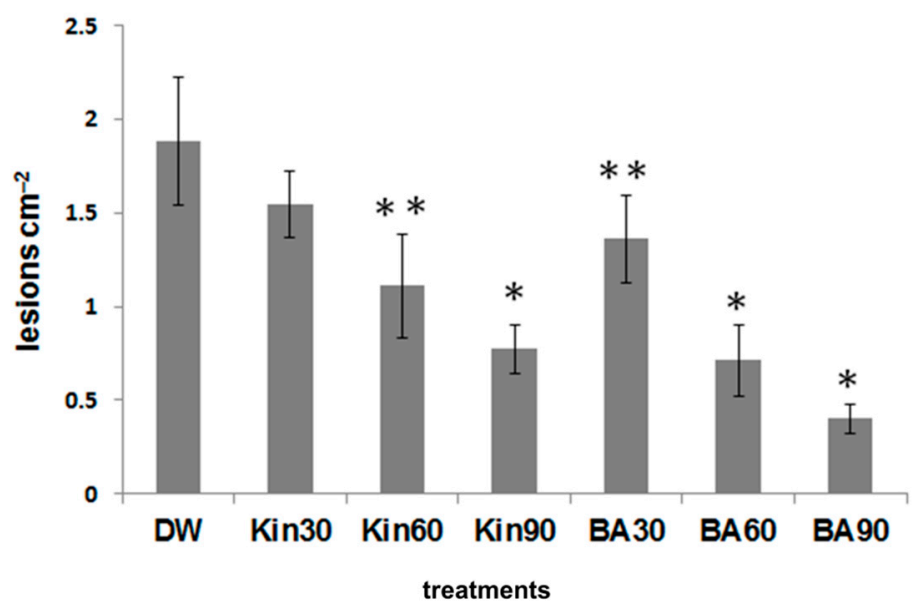

Figure 4. Effect of pre-treatments with various doses $(30 \mathrm{~mL}(1 \times 30), 60 \mathrm{~mL}(2 \times 30)$, and $90 \mathrm{~mL}$ $(3 \times 30))$ of saturated benzyladenine $(\mathrm{BA})$, kinetin $(\mathrm{KIN})$, or distilled water $(\mathrm{DW})$ on the number of TMV lesions on Xanthi tobacco leaves ( $3 \mathrm{dpi}$ ). Infection was carried out 2 days after the last treatment. Bars represent mean \pm standard deviations of three replicates of a representative experiment from two independent experiments with similar results. The significant difference from the corresponding water-treated control was determined $\left({ }^{*} p<0.001,{ }^{* *} p<0.05\right.$, two-tailed $t$-test).

Furthermore, the effect of pre-treatments with BA or kinetin on the reaction of plants to incompatible and compatible bacteria gave similar but somewhat surprising results. Electrolyte leakage from water, BA, or kinetin pre-treated Arabidopsis leaves after inoculation (brushing with bacterial suspension) with incompatible P.s. pv. s. 61 or compatible P.s. pv. t. DC3000 bacteria were measured 3 days after infection (Figure 5A). It is noteworthy that BA and kinetin treatments alone increased ion leakage. In water pre-treated leaves, the incompatible bacteria caused a significant $78 \%$ increase in conductivity (leakage of electrolytes) compared to its non-infected control, indicating the damage of plant cell membranes during HR in control leaves. In kinetin pre-treated leaves, the conductivity increase caused by the incompatible bacteria was smaller ( $49 \%$ increase as compared to its 
kinetin-treated non-infected control), and it was almost abolished in BA pre-treated plants (only $27 \%$ increase as compared to its non-infected control) (Figure 5A). Thus, similarly to TMV infection, the cell death and necrosis suppressor effect of BA was strong, while that of kinetin was much less expressed. On the other hand, as compared to the incompatible one, the compatible hemi-biotrophic bacteria caused much stronger leakage of electrolytes $3 \mathrm{dpi}$, which is probably due to vigorous multiplication and leaf spot disease-inducing ability of the bacteria in susceptible leaves (Figure 5A). However, surprisingly, while in BA, pre-treated leaves infection with P.s. pv. t. DC3000 bacteria increased ion leakage by $293 \%$ (compared to BA pre-treated non-infected leaves) and in water-treated control leaves by $241 \%$ (compared to non-infected control), in kinetin pre-treated leaves infection with P.s. pv. $t$. DC3000 bacteria increased ion leakage only by $75 \%$. Thus, in this respect, BA and kinetin treatments had the opposite effect on the reaction of Arabidopsis leaves to compatible bacteria since BA increased and kinetin decreased ion leakage.

A

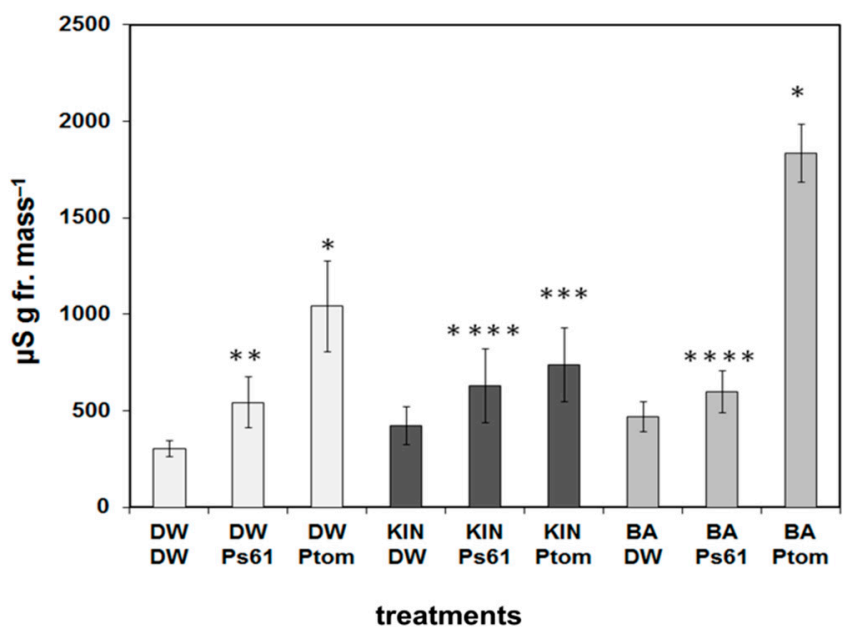

B

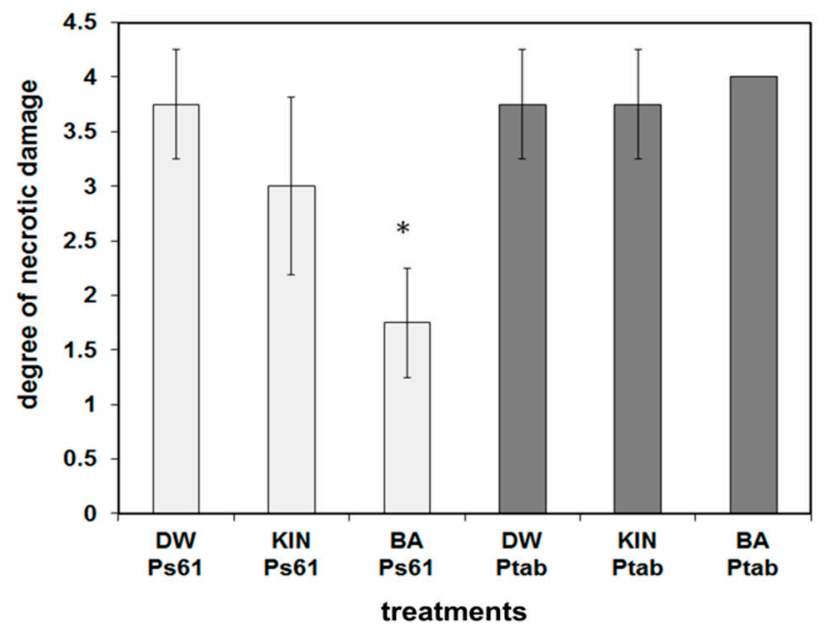

Figure 5. (A) Electrolyte leakage from water (DW), kinetin (KIN), or benzyladenine (BA) pre-treated Arabidopsis leaves at 3 dpi after inoculation with water (DW), incompatible P. s. pv. s. 61 (Ps61), or compatible P. s. pv. t. DC3000 (Ptom) bacteria. ${ }^{*} p<0.01,{ }^{* *} p<0.05,{ }^{* * *} p<0.1,{ }^{* * * *} p<0.2$ two-tailed $t$-test. (B) The reaction of water (DW), kinetin (KIN), or benzyladenine (BA) pre-treated tobacco plant leaves to incompatible P.s. pv. s. 61 (Ps61) or compatible P.s. pv. tabaci (Ptab) bacteria at $3 \mathrm{dpi}$ as evaluated by scoring (from 0 to 4 ) the necrotic damage caused by bacterial suspensions injected into tobacco leaves. $\mathrm{W}=$ water. ${ }^{*} p=0.001$ two-tailed $t$-test. Bars represent mean \pm standard deviations of three replicates of a representative experiment from three independent experiments with similar results. The significant difference from the corresponding water-treated control was determined.

In tobacco, by measuring the reaction of leaves to incompatible P.s. pv. s. 61 or compatible P.s. pv. tabaci bacteria, we got similar results, although the injection of compatible bacteria into tobacco leaves caused much stronger damage (disease development) than brushing Arabidopsis leaves with the same bacterial suspension. Therefore, the compatible bacteria caused total necrotization (score 4) of the injected leaf area in BA treated and only slightly less strong necrosis in water or kinetin-treated plants 3 days post inoculation (Figure 5B). On the other hand, the hypersensitive necrotic response caused by the incompatible bacteria was significantly suppressed again in leaves of BA pre-treated (46.7\%) and not significantly in the kinetin pre-treated ( $80 \%)$ tobacco plants as compared to the water-treated $(100 \%)$ ones (Figure 5B).

In order to learn the effect of the above cytokinin pre-treatments on the reaction of plants to necrotrophic fungi, leaves from BA or kinetin-treated tobacco plants were infected with agar discs from Botrytis cinerea 5-day-old culture and kept on wet filter paper in a Petri dish. As it can be seen from Figure 6, the pathogen caused very severe necrotic symptoms on leaves from water-treated plants, somewhat less on leaves from kinetin-treated plants, 
and significantly less on leaves from BA-treated plants, as is quantified by percentage of leaf necrosis.

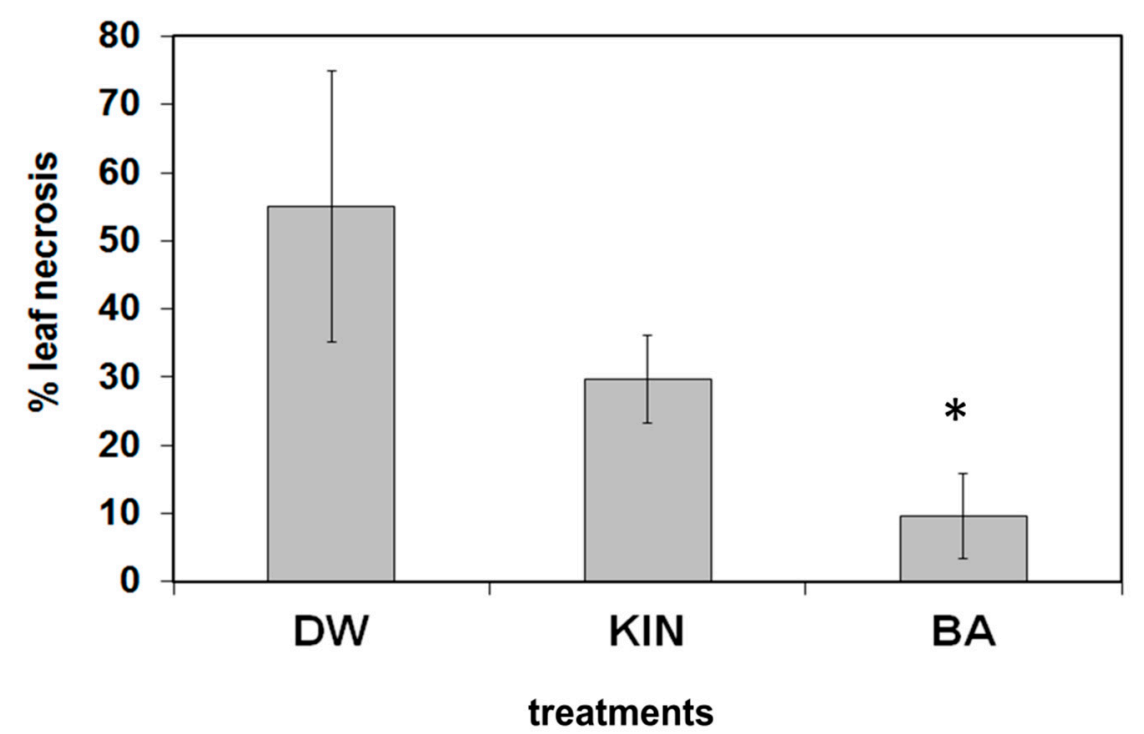

Figure 6. Effect of water (DW), kinetin (KIN), or benzyladenine (BA) pre-treatment on Botrytis cinerea infection on tobacco leaves. Pre-treated leaves were removed from tobacco plants and infected with a $0.5 \mathrm{~cm}$ in diameter agar culture disk of the pathogen in glass Petri dishes After 5 days, the extent of pathogen-induced leaf necrosis relative to the total leaf area was determined. Bars represent mean \pm standard deviations of three replicates of a representative experiment from three independent experiments with similar results. The significant difference from the corresponding water-treated control was determined $\left({ }^{*} p=0.019\right.$ two-tailed $t$-test).

\subsection{Benzyladenine Causes Stronger Transcriptomic Alterations Than Kinetin in Arabidopsis Leaves}

In order to obtain a wider picture of the plant responses to different cytokinin treatments and to find some answer for the possible background of different responses, we performed transcriptomic experiments. For gene expression measurements, Arabidopsis plants were treated with leaf brushing with BA or kinetin, and water-treated plants were used as a control. The transcriptomic changes were measured by Agilent Arabidopsis (V4) Gene Expression Microarray $(4 \times 44 \mathrm{~K})$. Gene expressions data of the microarray assays confirmed the diverse results of development and pathogen stress in BA and kinetin-treated plants.

After data processing, the results showed that at a significance level of adj.P.Val $<0.05$, only the BA treatment caused transcriptomic alterations compared to water-treated control. However, at a slightly lower significance level (adj.P.Val < 0.07), the kinetin treatment also showed many gene expression alterations. To confirm the reliability of the expression data at adj.P.Val $<0.07$, we performed qPCR measurements with 24 representative genes. We choose three representative genes from the eight group of genes (BA repressed/kinetin activated, BA activated/kinetin repressed, both BA and kinetin activated, both BA and kinetin repressed, only BA activated, only BA repressed, only kinetin activated, only kinetin repressed). The results of the qPCR tests practically corresponded to the microarray data. As it can be seen from Supplementary Table S2 and Figure 7, the qPCR results showed the same tendency and similar values as the microarray experiments (Pearson correlation coefficient value of $R$ is: 0.9523 ). Since the gene expression data were reliable at adj.P.Val $<0.07$, the results were further analysed at this significance level. BA treatments upregulated 1011 genes and downregulated 1011 genes, which were not changed after kinetin treatment (Figure 8). 


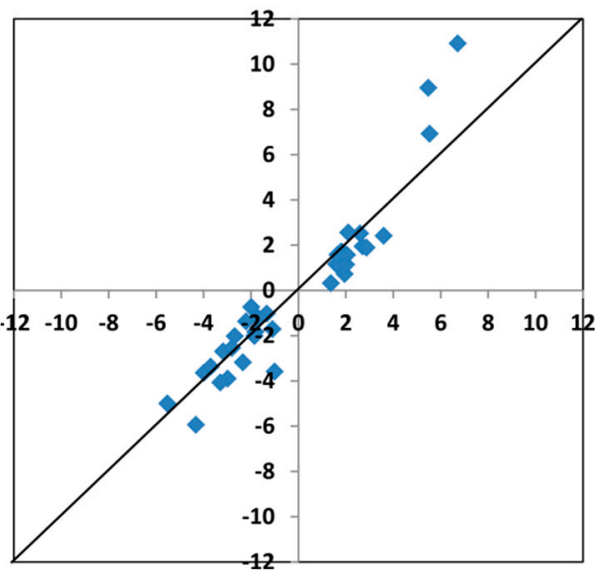

Figure 7. Comparison of expression changes of selected Arabidopsis genes detected with microarray and real-time RT-PCR after kinetin (KIN) or benzyladenine (BA) treatments. X-axes show the average $\log _{2}$ transcription activation or repression detected with microarray (up or downregulated in kinetin or benzyl adenine treatments leaves compared to water-treated control). Y-axes show the average $\log _{2}$ transcription activation or repression detected with real-time RT-PCR (up or downregulated in kinetin or benzyladenine treatments leaves compared to water-treated control).

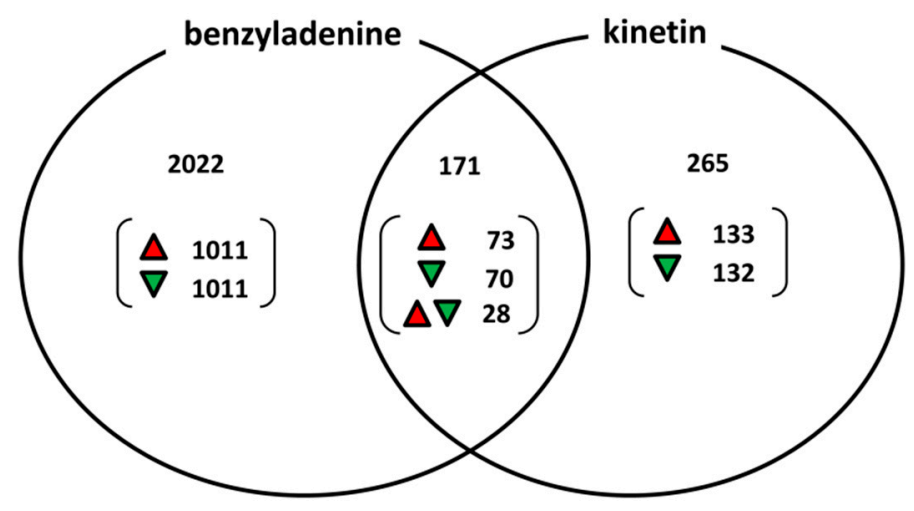

Figure 8. Number of up and downregulated genes after benzyladenine or kinetin treatments in Arabidopsis leaves. The figure shows the results of the microarray experiments. Genes activated or repressed significantly at least two times compared to water-treated control was indicated. $\mathbf{\Delta}$ = upregulated genes, $\boldsymbol{\nabla}$ = downregulated genes, $\mathbf{\Delta} \boldsymbol{\nabla}$ = genes regulated by the treatments to opposite directions.

In addition, not only the number of affected genes but the magnitude of the changes was much larger after BA than kinetin treatments (Supplementary Table S1). While the highest activation changes were about $100 \times$ induction among the BA-specific genes and the average induction was about $3.9 \times$, the highest activation after kinetin treatment was only $7.3 \times$ and the average induction was about $2.4 \times$. However, in spite of the much stronger effect of BA, we found 133 up and 132 downregulated genes whose activity was specifically modified by kinetin treatment and was not changed by BA (Figure 8). It is noteworthy that BA and kinetin treatment changed gene expressions into the same direction only in relatively few cases (73 upregulated and 70 downregulated genes); however, most interestingly, there were 28 genes where BA and kinetin treatments caused changes of gene expressions into the opposite directions (Figure 8, Table 1). The whole list of differentially regulated genes can be found in Supplementary Table S1. 
Table 1. Arabidopsis genes regulated by kinetin (Kin) or benzyladenine (BA) in opposite directions.

\begin{tabular}{|c|c|c|c|c|}
\hline \multirow{2}{*}{$\begin{array}{c}\text { Array ID a } \\
\text { A_84_P13657 }\end{array}$} & \multirow{2}{*}{$\begin{array}{c}\begin{array}{c}\text { Arabidopsis } \\
\text { TAIR Code }^{\text {b }}\end{array} \\
\text { AT3G29590 }\end{array}$} & \multicolumn{2}{|c|}{$\begin{array}{c}\text { Fold-Change }^{c} \\
\text { Kin BA }\end{array}$} & \multirow{3}{*}{\begin{tabular}{l}
\multicolumn{1}{c}{ Similarity, Function } \\
malonyl-CoA:anthocyanidin \\
5-O-glucoside-6'-O-malonyltransferase \\
transcription factor TT8
\end{tabular}} \\
\hline & & 2.0 & -1.8 & \\
\hline A_84_P18522 & AT4G09820 & 2.0 & -1.0 & \\
\hline A_84_P808177 & AT5G59320 & 1.7 & -4.3 & non-specific lipid-transfer protein 3 \\
\hline A_84_P12100 & AT5G25980 & 1.5 & -1.0 & myrosinase 2 (thioglucoside glucohydrolase) \\
\hline A_84_P842527 & AT5G42800 & 1.5 & -2.5 & DFR (dihydrokaempferol 4-reductase) \\
\hline A_84_P20780 & AT1G03495 & 1.4 & -1.8 & HXXXD-type acyl-transferase family protein \\
\hline A_84_P13548 & AT1G07430 & 1.3 & -1.2 & protein phosphatase $2 C 3$ \\
\hline A_84_P253555 & AT4G14090 & 1.2 & -2.2 & anthocyanin 5-O-glucosyltransferase \\
\hline A_84_P813812 & AT3G08770 & 1.2 & -1.8 & lipid-transfer protein 6 \\
\hline A_84_P12885 & AT4G22880 & 1.1 & -1.7 & leucoanthocyanidin dioxygenase \\
\hline A_84_P12954 & AT4G39210 & 1.1 & -1.0 & $\begin{array}{l}\text { glucose-1-phosphate adenylyltransferase large } \\
\text { subunit } 3\end{array}$ \\
\hline A_84_P804836 & AT1G68530 & 1.0 & -1.3 & 3-ketoacyl-CoA synthase 6 \\
\hline A_84_P750651 & AT1G59930 & -1.0 & 1.3 & maternally expressed imprinted protein \\
\hline A_84_P22866 & AT1G20070 & -1.0 & 1.5 & uncharacterized protein \\
\hline A_84_P860885 & AT2G05540 & -1.1 & 1.1 & glycine-rich protein \\
\hline A_84_P14446 & AT2G19190 & -1.1 & 3.6 & FLG22-induced receptor-like kinase 1 \\
\hline A_84_P18423 & AT3G47480 & -1.2 & 1.8 & putative calcium-binding protein CML47 \\
\hline A_84_P814710 & AT1G14870 & -1.3 & 1.9 & cadmium resistance protein 2 \\
\hline A_84_P51580 & AT1G72060 & -1.4 & 1.0 & serine-type endopeptidase inhibitor mRNA \\
\hline A_84_P544532 & AT1G58225 & -1.5 & 1.4 & uncharacterized protein \\
\hline A_84_P14903 & AT5G11920 & -1.6 & 1.3 & beta-fructofuranosidase \\
\hline A_84_P10728 & AT2G29110 & -1.7 & 1.4 & glutamate receptor 2.8 \\
\hline A_84_P511702 & AT1G53625 & -1.7 & 1.5 & uncharacterized protein \\
\hline A_84_P17225 & AT2G47190 & -2.0 & 1.2 & R2R3 MYB DNA binding domain transcription factor \\
\hline A_84_P827683 & AT1G65510 & -2.2 & 1.0 & uncharacterized protein \\
\hline A_84_P586318 & AT1G65845 & -2.2 & 1.2 & uncharacterized protein \\
\hline A_84_P737368 & AT1G36622 & -2.3 & 2.1 & uncharacterized protein \\
\hline
\end{tabular}

${ }^{a}$ Agilent Arabidopsis (V4) Gene Expression Microarray, $4 \times 44 \mathrm{~K}$ identifiers. ${ }^{\mathrm{b}}$ Arabidopsis TAIR gene identifiers. ${ }^{\mathrm{c}}$ gene expression in $\log _{2}$ transformed form compared to water-infiltrated control (average of three repeats), red and green backgrounds show up- and down-regulated genes, respectively. ${ }^{\mathrm{d}}$ genes involve in anthocyanin synthesis were highlighted by grey background.

Among the genes specifically activated by BA, the most upregulated (about 100 times) was a bifunctional inhibitor/lipid-transfer protein/seed storage $2 \mathrm{~S}$ albumin superfamily protein gene, while the most downregulated (more than 45 times) was a jasmonate-zimdomain protein gene. Furthermore, in addition to the other three bifunctional inhibitor/ lipid-transfer protein/seed storage $2 \mathrm{~S}$ albumin superfamilies, the most strongly upregulated genes by BA were a pathogenesis-related protein 1 (PR1) and defensin-like protein, LRR-receptor-like protein kinase, beta 1,3-glucanase, and a putative chitinase genes. It is also noteworthy that a cytokinin dehydrogenase 3 and three two-component response regulator ARR genes (negative regulators of cytokinin signals) were strongly upregulated by BA (Supplementary Table S1). Among the most downregulated genes by BA were three cytochrome P450 (family 94), lipoxygenase 3 and 4, two cold-regulated proteins, a pathogenesis-related thaumatin family protein gene, and two bifunctional inhibitor/lipidtransfer protein/seed storage $2 \mathrm{~S}$ albumin superfamily protein genes.

The most upregulated genes by both BA and kinetin were a gibberellin 20 oxidase 1 mRNA, three SAUR-like auxin-responsive protein mRNA, a gibberellin-regulated protein mRNA, three expansin (A8, A10, and an A11), a putative pectate lyase, as well as a dehydration-responsive element-binding protein $1 \mathrm{~A}$ genes. The most downregulated genes by both $\mathrm{BA}$ and kinetin were two ethylene-responsive transcription factors, a heat stress transcription factor, an abscisic acid receptor, three chaperone DNaJ-domain containing proteins, a calcium-binding protein, and calmodulin-like protein genes.

The most induced genes by kinetin and not BA treatments were Li-tolerant lipase 1 , two GDSL esterase/lipase, CBL-interacting protein kinase 5, a glucose-methanol-choline 
(GMC) oxidoreductase-like protein, a PATATIN-like 9 (phospholipase), two putative cinnamyl alcohol dehydrogenase 9 , and dehydration-responsive element-binding protein 3 genes. The most suppressed genes by only kinetin treatments were wall-associated receptor kinase-like 10, proline dehydrogenase 2, heat shock protein 70 , as well as class $\mathrm{V}$ 15.4, defence-like protein, and abscisic acid receptor PYL6 genes (Supplementary Table S1).

To find common and specific gene responses and plant processes induced by kinetin or BA treatments, the gene expression data were also compared by GO enrichment [36] and by MapMan analysis [37]. The difference of kinetin and BA-specific responses were supported by these comparisons and besides showed some common features of these treatments as well. The results pointed out that both treatments induced remarkable transcriptional reprogramming of the plant cells, but the BA had a stronger effect on transcription. The genes connected to the regulation of transcription were one of the most significantly enriched terms among BA-activated genes and among the BA-repressed genes, this term was also significantly enriched (Tables 2 and 3).

Table 2. Enrichment results of genes activated by benzyladenine.

\begin{tabular}{|c|c|c|c|}
\hline \multicolumn{4}{|c|}{ Biological Processes (998 Genes) } \\
\hline GO_acc & Term & Number of Genes ${ }^{a}$ & FDR $^{b}$ \\
\hline GO:0045449 & regulation of transcription $\mathrm{c}, \mathrm{d}$ & 93 & $2.70 \times 10^{-7}$ \\
\hline GO:0009735 & response to cytokinin stimulus & 16 & $1.70 \times 10^{-6}$ \\
\hline GO:0009739 & response to gibberellin stimulus & 20 & $2.70 \times 10^{-6}$ \\
\hline GO:0006260 & DNA replication & 17 & $4.00 \times 10^{-6}$ \\
\hline GO:0010876 & lipid localization & 9 & $5.90 \times 10^{-6}$ \\
\hline GO:0009733 & response to auxin stimulus & 30 & $7.20 \times 10^{-6}$ \\
\hline GO:0006949 & syncytium formation & 7 & $4.40 \times 10^{-5}$ \\
\hline GO:0009751 & response to salicylic acid stimulus & 20 & $5.90 \times 10^{-5}$ \\
\hline GO:0009828 & plant-type cell wall loosening & 8 & 0.0011 \\
\hline GO:0042742 & defence response to bacterium & 16 & 0.0016 \\
\hline GO:0009723 & $\overline{\text { response to ethylene stimulus }}$ & 17 & 0.0018 \\
\hline GO:0009699 & phenylpropanoid biosynthetic process & 14 & 0.0018 \\
\hline GO:0006979 & response to oxidative stress & 23 & 0.002 \\
\hline GO:0034976 & response to endoplasmic reticulum stress & 6 & 0.0026 \\
\hline GO:0009827 & plant-type cell wall modification & 8 & 0.0033 \\
\hline GO:0009791 & post-embryonic development & 37 & 0.0034 \\
\hline GO:0042254 & ribosome biogenesis & 18 & 0.004 \\
\hline GO:0006334 & nucleosome assembly & 8 & 0.0057 \\
\hline GO:0045454 & cell redox homeostasis & 9 & 0.0058 \\
\hline GO:0007623 & circadian rhythm & 9 & 0.007 \\
\hline GO:0009753 & response to jasmonic acid stimulus & 16 & 0.0076 \\
\hline GO:0010114 & response to red light & 9 & 0.0079 \\
\hline GO:0009933 & meristem structural organization & 7 & 0.016 \\
\hline GO:0009627 & systemic acquired resistance & 7 & 0.018 \\
\hline GO:0050832 & defence response to fungus & 10 & 0.018 \\
\hline GO:0009611 & response to wounding & 14 & 0.022 \\
\hline GO:0046686 & response to cadmium ion & 13 & 0.025 \\
\hline GO:0048509 & regulation of meristem development & 8 & 0.025 \\
\hline GO:0006874 & cellular calcium ion homeostasis & 5 & 0.036 \\
\hline GO:0051726 & regulation of cell cycle & 10 & 0.046 \\
\hline GO:0009825 & multidimensional cell growth & 6 & 0.047 \\
\hline
\end{tabular}

${ }^{a}$ number of genes associated with the GO term. ${ }^{b}$ FDR $<0.05$ was selected as significant enrichment. ${ }^{c}$ terms common with kinetin-activated terms were highlighted by gray background. ${ }^{d}$ terms common with BA-repressed terms were underlined. 
Table 3. Enrichment results of genes repressed by benzyladenine.

\begin{tabular}{|c|c|c|c|}
\hline \multicolumn{4}{|c|}{ Biological Processes (930 Genes) } \\
\hline GO_acc & Term & Number of Genes ${ }^{a}$ & FDR ${ }^{b}$ \\
\hline GO:0009409 & response to cold $^{\mathrm{C}}$ & 47 & $7.20 \times 10^{-18}$ \\
\hline GO:0009414 & response to water deprivation & 39 & $5.60 \times 10^{-17}$ \\
\hline GO:0006970 & response to osmotic stress & 50 & $1.40 \times 10^{-16}$ \\
\hline GO:0009611 & response to wounding ${ }^{d}$ & 35 & $1.00 \times 10^{-15}$ \\
\hline GO:0010200 & response to chitin & 31 & $2.10 \times 10^{-15}$ \\
\hline GO:0009737 & response to abscisic acid stimulus & 45 & $1.60 \times 10^{-14}$ \\
\hline GO:0009753 & response to jasmonic acid stimulus & 31 & $8.20 \times 10^{-12}$ \\
\hline GO:0051707 & response to other organism & 48 & $8.20 \times 10^{-10}$ \\
\hline GO:0006952 & defense response & 53 & $1.10 \times 10^{-8}$ \\
\hline GO:0009695 & jasmonic acid biosynthetic process & 9 & $1.40 \times 10^{-5}$ \\
\hline GO:0006979 & response to oxidative stress & 27 & $1.40 \times 10^{-5}$ \\
\hline GO:0019684 & photosynthesis, light reaction & 14 & $4.40 \times 10^{-5}$ \\
\hline GO:0005983 & starch catabolic process & 6 & 0.00031 \\
\hline GO:0009723 & response to ethylene stimulus & 17 & 0.00068 \\
\hline GO:0045449 & regulation of transcription & 74 & 0.00069 \\
\hline GO:0006855 & multidrug transport & 10 & 0.00088 \\
\hline GO:0010876 & lipid localization & 6 & 0.0015 \\
\hline GO:0006863 & purine transport & 6 & 0.0021 \\
\hline GO:0010035 & response to inorganic substance & 19 & 0.0026 \\
\hline GO:0019761 & glucosinolate biosynthetic process & 7 & 0.0027 \\
\hline GO:0052482 & cell wall thickening during defense response & 5 & 0.0028 \\
\hline GO:0019762 & glucosinolate catabolic process & 5 & 0.004 \\
\hline GO:0052543 & callose deposition in cell wall & 5 & 0.004 \\
\hline GO:0042742 & defense response to bacterium & 14 & 0.004 \\
\hline GO:0042435 & indole derivative biosynthetic process & 7 & 0.0049 \\
\hline GO:0009718 & anthocyanin biosynthetic process & 5 & 0.0055 \\
\hline GO:0050832 & defense response to fungus & 10 & 0.0088 \\
\hline GO:0034641 & cellular nitrogen compound metabolic process & 26 & 0.0089 \\
\hline GO:0009626 & plant-type hypersensitive response & 7 & 0.01 \\
\hline GO:0005984 & disaccharide metabolic process & 6 & 0.02 \\
\hline GO:0000302 & response to reactive oxygen species & 8 & 0.026 \\
\hline GO:0006865 & amino acid transport & 7 & 0.026 \\
\hline GO:0009751 & response to salicylic acid stimulus & 13 & 0.028 \\
\hline GO:0009407 & toxin catabolic process & 6 & 0.038 \\
\hline GO:0009639 & response to red or far red light & 13 & 0.04 \\
\hline GO:0065008 & regulation of biological quality & 29 & 0.041 \\
\hline GO:0006796 & phosphate metabolic process & 45 & 0.045 \\
\hline
\end{tabular}

${ }^{a}$ number of genes associated with the GO term. ${ }^{b}$ FDR $<0.05$ was selected as significant enrichment. ${ }^{c}$ terms common with kinetin-repressed terms were highlighted by gray background. ${ }^{\mathrm{d}}$ terms common with BA-activated terms were underlined.

The kinetin treatments also induced significant enrichment among upregulated genes related to gene regulation but not among downregulated ones (Tables 4 and 5). According to enrichment analysis, high numbers of up or downregulated transcription factors were showed by MapMan results (data not shown). Other typical common features of kinetin and BA on gene expression were that both treatments influenced the different hormonerelated responses. Interestingly, only BA-activated genes had a significant impact on cytokinin-induced processes (Table 2), but both treatments had a significant effect on auxin and gibberellin-related stimulus (Tables 2 and 4). In addition, BA influenced some well-known defence-related hormone response such as salicylic acid, jasmonic acid, and ethylene responses in both activated and repressed genes (Tables 2 and 3). It is remarkable that BA repressed several consecutive steps of JA synthesis, but in the case of kinetin treatments, this was not discernible (Supplementary Figure S1). 
Table 4. Enrichment results of genes activated by kinetin.

\begin{tabular}{cccc}
\hline & Biological Processes (199 Genes) & & \\
\hline GO_acc & Term & Number of Genes $^{\text {a }}$ & FDR $^{\mathbf{b}}$ \\
\hline GO:0009826 & unidimensional cell growth & 10 & $1.60 \times 10^{-5}$ \\
GO:0007169 & transmembrane receptor protein tyrosine kinase signalling pathway & 8 & $6.50 \times 10^{-5}$ \\
GO:0009828 & plant-type cell wall loosening c & 5 & 0.00012 \\
GO:0009825 & multidimensional cell growth & 5 & 0.00027 \\
GO:0009699 & phenylpropanoid biosynthetic process & 7 & 0.00034 \\
GO:0009813 & flavonoid biosynthetic process & 5 & 0.00092 \\
GO:0048646 & anatomical structure formation involved in morphogenesis & 6 & 0.0012 \\
GO:0006073 & cellular glucan metabolic process & 5 & 0.0022 \\
GO:0006631 & fatty acid metabolic process & 7 & 0.004 \\
GO:0009739 & response to gibberellin stimulus & 6 & 0.004 \\
GO:0046148 & pigment biosynthetic process & 5 & 0.0055 \\
GO:0006260 & DNA replication & 5 & 0.0063 \\
GO:0009733 & response to auxin stimulus & 8 & 0.0094 \\
GO:0045449 & regulation of transcription & 20 & 0.016 \\
GO:0006468 & protein amino acid phosphorylation & 5 & 0.018 \\
GO:0009611 & response to wounding & 5 & 0.036 \\
\hline
\end{tabular}

${ }^{a}$ number of genes associated with the GO term. ${ }^{b}$ FDR $<0.05$ were selected as significant enrichment. ${ }^{c}$ terms common with BA-activated terms were highlighted by gray background.

Table 5. Enrichment results of genes repressed by kinetin.

\begin{tabular}{cccc}
\hline & \multicolumn{2}{c}{ Biological Processes (201 Genes) } & \\
\hline GO_acc & Term & Number of Genes $^{\mathbf{a}}$ & FDR $^{\mathbf{b}}$ \\
\hline GO:0010200 & response to chitin c & 10 & $3.50 \times 10^{-6}$ \\
GO:0006979 & response to oxidative stress & 6 & $6.60 \times 10^{-6}$ \\
GO:0009408 & response to heat & 8 & 0.013 \\
GO:0009409 & response to cold & 7 & 0.019 \\
GO:0010035 & response to inorganic substance & 10 & 0.031 \\
GO:0051707 & response to other organism & 8 & 0.049 \\
GO:0006970 & response to osmotic stress & 0.05 \\
\hline
\end{tabular}

${ }^{a}$ number of genes associated with the GO term. ${ }^{b}$ FDR $<0.05$ were selected as significant enrichment. ${ }^{c}$ terms common with BA-repressed terms were highlighted by gray background.

The enrichment analysis also revealed that both treatments activate cell wall looseningrelated genes that may connect to cell growth, whose genes are also upregulated by the two treatments (Tables 2 and 4). Based on gene expression results, there were some other general processes that influenced by BA but not kinetin, such as protein synthesis and photosynthesis. BA significantly affected ribosome biogenesis and activated many ribosome structural genes, while repressed several genes involve in photosynthesis light reaction (Tables 2 and 3). Other noteworthy differences can be seen in relation to the phenylpropanoid/flavonoid/anthocyanin biosynthetic processes. Although both treatments significantly enriched upregulated genes related to the phenylpropanoid biosynthetic process (Tables 2 and 4), in the case of kinetin, the direction of the changes was more uniform, since all detected genes were activated (Supplementary Figure S2). In contrast, the picture after BA treatment is more complex, because mainly, the early steps of phenylpropanoid synthesis were upregulated and almost all flavonoid/anthocyanin synthesis genes were repressed (Supplementary Figures S2 and S3). Moreover, some genes related to anthocyanin biosynthesis are part of the common genes regulated in the opposite direction by BA and kinetin (repressed by BA and activated by kinetin (Table 1). Finally, the results also showed that the plant defence-related processes are more affected by BA than kinetin. After the BA treatment, the defence-related genes were enriched in both the activated and repressed genes such as genes related to resistance against bacteria and fungus, which may refer to complex changes induced by BA in plant cells (Tables 2 and 3). On the other hand, kinetin 
did not cause significant enrichment defence-related changes among upregulated genes at all (Table 4).

\section{Discussion}

Although there are a large amount of data about the effect of cytokinins on various aspects of plant development [38-41], the number of publications comparing the effect of two different cytokinins on plants are limited. Our data provide new and somewhat astonishing data on the different effect of two structurally similar cytokinins. We obtained the first surprising results when Arabidopsis leaves were brushed with the solutions of BA, kinetin, or water. BA solution inhibited the development of flowering stem, while kinetin treatment rather promoted it as compared to the water-treated ones (Figure 1A). As regards the mechanisms of the effect of cytokinins on plant growth, it is noteworthy that cytokinins are considered as inhibitors of root growth and promoters of shoot growth [1]. Although Cajanus cajan L. plants showed a significant increase in branch number, leaf number, leaf area, and seed mass to kinetin treatment [42], our results suggest that Arabidopsis is much more sensitive to BA, and its effect is "too strong", therefore inhibitory, while the sensitivity to kinetin is much less, and this treatment seemed to stimulate development of the flowering stem. The different effects of these two cytokinins on plants were further supported by experiments in which test solutions were sprinkled to the root at the early stages of the seedling. BA strongly inhibited the development of both Arabidopsis and tobacco plants, whereas kinetin had no such effect. (Figure 1B,C). Furthermore, the general observation of the experiments was that diluted BA had little or no effect on plant phenotypes compared to the saturated solution, and kinetin did not cause or could cause a slight phenotypic change at most only as a saturated solution. These changes had been seen in the cases of Arabidopsis flower development and tobacco small leaves formation induction as well (data not shown). Accordingly, Argueso et al. [3] showed that high concentrations of cytokinin lead to increased defence responses to a virulent oomycete pathogen through a process that is dependent on salicylic acid (SA) accumulation and activation of defence gene expression. However, treatment with lower concentrations of cytokinin resulted in increased susceptibility. Similar results are seen in response to wheat to powdery mildew [43]. However, we have to point out that in our experiments, the lower molar concentration of BA had a much stronger effect than a higher molar concentration of another cytokinin kinetin. The chlorophyll content of the second oldest leaves of tobacco plants also showed correlation with the amount of the applied cytokinins. BA was more efficient in the retardation of both chlorophyll $a$ and $b$ degradation, but higher doses of kinetin were more effective than the lowest doses of BA (Figure 2), and the lowest doses of kinetin had no inhibitory effect on chlorophyll degradation as compared to the control water-treated tobaccos leaves. All these data indicate that the senescence inhibiting and developmental effect of both cytokinins depends on their doses of application. In addition, it is known that different cytokinins have different binding affinities for the histidine kinases, which function as their cognate receptors in plants. Such differences have been well documented biochemically for Arabidopsis. For example, BA has a 10-fold lower affinity for HK receptors in Arabidopsis than the naturally occurring trans-zeatin [44]. Thus, the intensity of signal transduction resulting from the use of similar concentrations of different cytokinin species can be different in plant cells (due to their different affinity for cognate receptors). This is in fact corroborated by the gene expression studies performed in the present study: While the foliar applications of BA in the $\mathrm{mM}$ range had a clear effect on upregulating cytokinin-responsive genes, an even $30 \%$ higher concentration of kinetin did not do so.

It is noteworthy that in our experiments, in addition to plant development, BA had a much stronger effect on drought tolerance than kinetin treatment, especially in the case of Arabidopsis plants (data not shown). In accordance, there are reports about the protecting effect of cytokinin treatments to drought, salt, and generally abiotic stresses [42,45-47], which is probably due to the elevated stress tolerance of juvenile plant tissues [14]. In 
addition, we should emphasize that the hormonal control of plant development and stress adaptation is the outcome of a complex network of multiple synergistic and antagonistic interactions between various plant hormones [48-52].

In spite of the ever-increasing number of publications on the mechanisms of plant resistance to pathogens, there are still many open questions [15-17]. The importance of plant hormones and especially cytokinins in plant disease development and in plant immunity is discussed in several papers [18,53-57]. The stronger effect of BA treatment was also experienced in the case of pathogen-induced stresses; however, in these cases, the picture was complicated by the effect of these treatments on the in planta multiplication of the pathogens. Namely, the hypersensitive necrotic symptoms are not always in correlation with resistance to the pathogen [58]. BA treatment of tobacco plants strongly reduced TMV-induced lesion development on leaves, while kinetin treatment weakly reduced TMVinduced lesion development on leaves, which was also shown by the conductivity assay (Figure 3). It is also noteworthy that in the case of all treatments, the number of lesions was significantly reduced in the younger upper than older lower tobacco leaves. However, in our previous publication, we proved that the number of lesions caused by TMV infection and virus multiplications are not always in correlation [56]. Accordingly, the HR caused by the incompatible P. s. pv. s. 61 bacteria was significantly reduced by BA and much less by kinetin pre-treatment in tobacco leaves. However, the compatible P. s. pv. tabaci caused leaf necrosis to a similar extent on water, kinetin, or BA pre-treated plants (Figure 5B). These results are in agreement with our previous data where cytokinin-overproducing tobacco showed elevated tolerance to incompatible $P$. syringae-induced $\mathrm{HR}$ but not to the necrosis caused by compatible P. s. pv. tabaci. Moreover P. s. pv. tabaci showed higher multiplication in cytokinin-overproducing than in the control not transformed tobacco leaves [23]. In the case of Arabidopsis, we obtained similar results. The incompatible bacteria caused the largest membrane damage (ion leakage) in water-treated, while it caused the smallest in BA-treated plants compared to their non-infected controls. Connection of cytokinin and the cell death process was further supported by the fact that the protein Bax Inhibitor-1 (BI-1), a negative regulator of plant programmed cell death (PCD), was upregulated following treatments with cytokinins [59].

On the other hand, the compatible bacteria induced the strongest leakage of ions from leaves of the BA-treated plants (Figure 5A). This phenomenon is most probably due to the stronger multiplication of compatible bacteria in juvenile tissues, as we found earlier $[23,30]$. However, it is noteworthy that BA and kinetin treatments had the opposite effect on the reaction of Arabidopsis leaves to compatible bacteria, since BA increased membrane damage (ion leakage) but kinetin decreased membrane damage (ion leakage) compared to the water-treated ones (Figure 5A).

The picture of the reactions of the treated plants to the necrotrophic pathogen Botrytis cinerea infection was clearer. BA treatment suppressed the necrotic disease symptoms and membrane damage (Figure 6). Since cytokinins inhibit leaf senescence $[60,61]$ and necrotrophic pathogens prefer the senescent older plant tissues, therefore, not only the necrotic symptoms but the development of the pathogen is also suppressed in juvenile tissues [23,28].

Regarding the mechanisms, we think that the enhanced tolerance of juvenile plant tissues to necrotic pathogenic stress is due to, partly at least, to their more stable membranes $[62,63]$ and elevated antioxidant capacity $[14,22-24]$, as we proved also in the case of transgenic ferritin overproducing tobacco by inhibiting the formation of the most harmful reactive oxygen, the hydroxyl radical [64].

Our gene expression data confirmed the diverse effect of kinetin and BA on Arabidopsis plants. There are several papers dealing with gene expressions of cytokinin-treated Arabidopsis [5,6,65-67]. However, as it is explained by Bhargava et al. [68], it is difficult to compare the results of various papers because of different lab/growth and treatment-specific effects. To check how our transcriptomic results relate to previous cytokinin-induced experiments, we compared these results with some gene lists obtained from publications 
that summarise several microarray experiments (Supplementary Table S3). It was clear from the comparisons that the results also depended on the gene expression platforms used for transcriptomics. Brenner et al. [65,67] published the TOP 25 cytokinin-activated genes of meta-analysis of Affymetrix ATH1 and CATMA microarrays. From the TOP 25 ATH1 genes, $17(68 \%)$ were found in our BA-treated samples, and from the TOP 25 CATMA array, 12 genes $(48 \%)$ were found in our BA-treated samples. The kinetin treatments have only limited overlapping with these TOP 25 gene lists, since one and two genes were common with ATH1 and CATMA genes, respectively. Bhargava et al. [68] published two more detailed lists of cytokinin-regulated genes. One of these lists is based on a meta-analysis of 13 ATH1 type array experiments and produced a so-called golden list of cytokinin-regulated genes of Arabidopsis that contains 226 genes (158 upregulated and 68 downregulated). From these 226 genes, about 35\% (78) were influenced significantly in our BA-treated and only $4 \%$ (9) were influenced significantly by kinetin. The other cytokinin-regulated list obtained from analysis of an RNA-seq based method contains 375 significantly regulated genes (226 upregulated and 149 downregulated) and about 28\% (104) were influenced significantly in our BA-treated and again only $4 \%$ (16) were influenced significantly by kinetin. The low level of overlapping between our kinetin treatment and the results of cytokinin-modified genes list obtained by meta-analysis could be due to using BA or zeatin in the experiments for meta-analyses.

It is difficult to pick up individual genes from the almost 2500 transcriptionally altered genes that are definitely responsible for the changes in response to cytokinin treatments. However, some tendencies in the gene expression changes can be recognized. First of all, BA solution had stronger effect than kinetin solution not only on the biotic stress tolerance of Arabidopsis plants but also on gene expressions. The larger amount of up and downregulated genes by BA treatments can be probably explained by the higher binding affinities for receptors. However, in spite of the more than 2000 genes that exclusively changed their expression after BA treatment, there were 265 up or downregulated genes that changed their expressions only by kinetin treatment. More surprisingly, there were only 73 up and 70 downregulated genes that altered their expression in the same direction after both cytokinin treatments. These latter results, together with the 28 genes that change their expressions into the opposite direction after BA and kinetin treatments, emphasise the diverse effect of these cytokinins on plant processes (Figure 8).

One group of genes that we should recognize are hormone-related genes. Both BA and kinetin treatments upregulated a gibberellin oxidase gene (AT4G25420), a gibberellinregulated gene (AT2G14900), and three SMALL AUXIN UPREGULATED (SAUR)-like auxin-responsive genes (AT4G34770, AT4G34790, AT3G03820), while they downregulated two ethylene-responsive transcription factors (AT2G20880, AT1G22810) and an abscisic acid receptor gene (AT5G05440). Furthermore, a cytokinin dehydrogenase 3 (AT5G56970) and three two-component response regulator ARR genes (negative regulators of cytokinin signals, AT5G62920, AT1G74890, AT3G48100) were strongly upregulated, while a jasmonatezim-domain gene (AT2G34600) was strongly downregulated by BA. Additionally, an abscisic acid receptor mRNA gene (AT2G40330) was downregulated by kinetin treatment. All these data strengthened the hypothesis on the concerted action of the network of plant hormones [5].

The other interesting group consists of the pathogenesis-related genes. BA treatment strongly upregulated a pathogenesis-related protein 1 (PR1, AT2G14610), a defensinlike protein (AT1G19610), an LRR-receptor-like protein kinase (AT1G51890), a beta 1,3glucanase (PR2, AT3G57260), and a putative chitinase gene (AT2G43570). Interestingly, a pathogenesis-related thaumatin family gene (AT4G36010) was downregulated by BA treatment. On the other hand, kinetin treatment did not upregulate pathogenesis-related proteins but downregulated a defence-like protein mRNA.

An additional group is formed by stress-related genes. BA suppressed two coldregulated protein genes (AT2G42540, AT5G42900), while genes At5MAT (AT3G29590) and TT8 (AT4G09820) involved in flavonoid/anthocyanin metabolism were downregu- 
lated by BA and upregulated by kinetin. It is noteworthy that a dehydration-responsive element-binding gene (AT4G25480) was among the most upregulated genes by both BA and kinetin, which can be related to an increase in draught tolerance. Among the most downregulated genes by both BA and kinetin was a heat stress transcription factor gene (AT2G26150). Kinetin treatment alone upregulated a dehydration-responsive elementbinding gene (AT2G26150) but downregulated a heat shock protein 70 gene (AT5G02490). Interplay between biotic, abiotic, and hormone-related responses were also experienced previously by analysing transcriptomic data in different plant pathogen interactions [69,70]. It is also noteworthy that kinetin treatment affected lipase and phospholipase genes. Accordingly, the most induced genes by kinetin and not BA treatments were Li-tolerant lipase (AT3G04290), two GDSL esterase/lipase (AT5G33370, AT4G28780), and a PATATIN-like 9 (phospholipase, AT3G63200).

The other group of genes induced by kinetin and not BA treatments consisted of oxido-reductase enzymes, such as a glucose-methanol-choline (GMC) oxidoreductase-like gene (AT1G12570) and putative cinnamyl alcohol dehydrogenase 9 genes (AT4G39330). In addition, among the most suppressed genes by only kinetin treatment was a proline dehydrogenase 2 gene (AT5G38710). BA repressed allene oxide cyclase 1 (AT3G25760).

Naturally, we could separate the other group of genes that show characteristic changes after BA or kinetin treatment, but we think that the above selected groups of genes are possibly involved in the various responses of the two cytokinin-treated plants.

In conclusion, we obtained different, sometimes opposite, effects of kinetin and benzyladenine treatments on development and tolerance to virus, bacteria as well as to fungal infection of Arabidopsis and tobacco plants. Generally, BA treatment had a much stronger effect on the development and stress tolerance of both plants than treatments with kinetin, which were reflected in the changes in gene expression profiles of Arabidopsis as reactions to treatments with the two cytokinins. The stronger protective effect of BA to necrotic stresses is probably due to its stronger effect on plant tissues to inhibit senescence, as was shown by the chlorophyll contents in leaves of the cytokinin-treated plants. The practical application of the BA-induced biotic and abiotic stress tolerance needs further investigations, which is under progress.

Supplementary Materials: The following are available online at https://www.mdpi.com/article/ 10.3390/life11121404/s1, Figure S1: Benzyladenine (BA) repressed several consecutive steps of JA synthesis, Figure. S2: Effect of kinetin (A) and benzyladenine (B) on gene expressions related to secondary metabolism, Figure. S3: Effect of kinetin (A) and benzyladenine (B) on gene expressions related to secondary metabolism, Table S1: Genes significantly up or downregulated after kinetin or benzyladenine treatments, Table S2: Primers of selected Arabidopsis genes used by real-time RTPCR for validating microarray results, Table S3: Comparison of kinetin and benzyladenine induced Arabidopsis gene expression results with previously published cytokinin-responsive gene lists.

Author Contributions: Conceptualization, B.B.; methodology, B.B. and Z.B.; investigation, B.B. and Z.B.; data curation, B.B. and Z.B.; writing-original draft preparation, B.B. and Z.B.; writing-review and editing, B.B. and Z.B.; funding acquisition, B.B. All authors have read and agreed to the published version of the manuscript.

Funding: This research was funded by Hungarian Scientific Research Fund (OTKA K83615).

Institutional Review Board Statement: Not applicable.

Informed Consent Statement: Not applicable.

Data Availability Statement: Data are contained within the article and in the Supplementary Materials (Figures S1-S3, Tables S1-S3).

Conflicts of Interest: The authors declare no conflict of interest. 


\section{References}

1. Werner, T.; Motyka, V.; Strnad, M.; Schmülling, T. Regulation of plant growth by cytokinin. Proc. Natl. Acad. Sci. USA 2001, 98, 10487-10492. [CrossRef]

2. Nishiyama, R.; Watanabe, Y.; Fujita, Y.; Le, D.T.; Kojima, M.; Werner, T.; Vankova, R.; Yamaguchi-Shinozaki, K.; Shinozaki, K.; Kakimoto, T.; et al. Analysis of cytokinin mutants and regulation of cytokinin metabolic genes reveals important regulatory roles of cytokinins in drought, salt and abscisic acid responses, and abscisic acid biosynthesis. Plant Cell 2011, 23, 2169-2183. [CrossRef]

3. Argueso, C.T.; Ferreira, F.J.; Epple, P.; To, J.P.C.; Hutchison, C.E.; Schaller, G.E.; Dangl, J.E.; Kieber, J.J. Two-component elements mediate interactions between cytokinin and salicylic acid in plant immunity. PLoS Genet. 2012, 8, e1002448. [CrossRef]

4. Osugi, A.; Sakakibara, H. Q\&A: How do plants respond to cytokinins and what is their importance? BMC Biol. 2015, 13, 102. [CrossRef]

5. Hwang, I.; Sheen, J.; Muller, B. Cytokinin signalling networks. Annu. Rev. Plant Biol. 2012, 63, 353-380. [CrossRef] [PubMed]

6. Potter, K.C.; Wang, J.; Schaller, G.E.; Kieber, J.J. Cytokinin modulates context-dependent chromatin accessibility through the type-B response regulators. Nat. Plants 2018, 4, 1102-1111. [CrossRef]

7. Barciszewski, J.; Siboska, G.E.; Pedersen, B.O.; Clark, B.F.; Rattan, S.I. Evidence for the presence of kinetin in DNA and cell extracts. FEBS Lett. 1996, 393, 197-200. [CrossRef]

8. Pokorná, E.; Hluska, T.; Galuszka, P.; Hallmark, H.T.; Dobrev, P.I.; Záveská Drábková, L.; Filipi, T.; Holubová, K.; Plíhal, O. Cytokinin N-glucosides: Occurrence, Metabolism and Biological Activities in Plants. Biomolecules 2021, 11, 24. [CrossRef]

9. Jablonska-Trypuc, A.; Matejczyk, M.; Czerpak, R. N6-benzyladenine and kinetin influence antioxidative stress parameters in human skin fibroblasts. Mol. Cell. Biochem. 2016, 413, 97-107. [CrossRef] [PubMed]

10. Othman, E.M.; Naseem, M.; Awad, E.; Dandekar, T.; Stopper, H. The plant hormone cytokinin confers protection against oxidative stress in mammalian cells. PLoS ONE 2016, 11, e0168386. [CrossRef] [PubMed]

11. Zhang, Y.; Wang, H.-L.; Li, Z.; Guo, H. Genetic Network between Leaf Senescence and Plant Immunity: Crucial Regulatory Nodes and New Insights. Plants 2020, 9, 495. [CrossRef] [PubMed]

12. Glazebrook, J. Contrasting mechanisms of defense against biotrophic and necrotrophic pathogens. Annu. Rev. Phytopathol. 2005, 43, 205-227. [CrossRef] [PubMed]

13. Häffner, E.; Konietzki, S.; Diederichsen, E. Keeping control: The role of senescence and development in plant pathogenesis and defense. Plants 2015, 4, 449-488. [CrossRef] [PubMed]

14. Barna, B.; Fodor, J.; Harrach, B.D.; Pogány, M.; Király, Z. The Janus face of reactive oxygen species in resistance and susceptibility of plants to necrotrophic and biotrophic pathogens. Plant Physiol. Biochem. 2012, 59, 37-43. [CrossRef]

15. Loake, G.J. Molecular aspects of plant disease resistance. Annual Plant Reviews Volume 34. Ann. Bot. 2009, 104, v. [CrossRef]

16. Yu, X.; Feng, B.; He, P.; Shan, L. From chaos to harmony: Responses and signaling upon microbial pattern recognition. Annu. Rev. Phytopathol. 2017, 55, 109-137. [CrossRef] [PubMed]

17. Andersen, E.J.; Ali, S.; Byamukama, E.; Yen, Y.; Nepal, M.P. Disease resistance mechanisms in plants. Genes 2018, 9, 339. [CrossRef] [PubMed]

18. Choi, J.; Choi, D.; Lee, S.; Ryu, C.M.; Hwang, I. Cytokinins and plant immunity: Old foes or new friends? Trends Plant Sci. 2011, 16, 389-394. [CrossRef]

19. Grosskinsky, D.B.; Edelsbrunner, K.; Pfeifhofer, H.; van Der Graaff, E.; Roitsch, T. Cis- and trans-zeatin differentially modulate plant immunity. Plant Signal. Behav. 2013, 8, e24798. [CrossRef]

20. Akhtar, S.S.; Mekureyaw, M.F.; Pandey, C.; Roitsch, T. Role of cytokinins for interactions of plants with microbial pathogens and pest insects. Front. Plant Sci. 2020, 10, 1777. [CrossRef]

21. Naseem, M. Role of Cytokinins in Plant Immunity. Ph.D. Thesis, Julius-Maximilians-Universität, Würzburg, Germany, 2009.

22. Pogány, M.; Koehl, J.; Heiser, I.; Elstner, E.F.; Balázs, B. Juvenility of tobacco induced by cytokinin gene introduction decreases susceptibility to Tobacco necrosis virus and confers tolerance to oxidative stress. Phys. Mol. Plant Path. 2004, 65, 39-47. [CrossRef]

23. Barna, B.; Smigocki, A.C.; Baker, J.C. Transgenic production of cytokinin suppresses bacterially induced HR symptoms and increases antioxidative enzyme levels in Nicotiana. Phytopathology 2008, 98, 1242-1247. [CrossRef]

24. Gullner, G.; Juhász, C.; Németh, A.; Barna, B. Reactions of tobacco genotypes with different antioxidant capacities to powdery mildew and Tobacco mosaic virus infections. Plant Physi. Biochem. 2017, 119, 232-239. [CrossRef]

25. Fodor, J.; Gullner, G.; Ádám, A.L.; Barna, B.; Kőmíves, T.; Király, Z. Local and systemic responses of antioxidants to tobacco mosaic virus infection and to salicylic acid in tobacco: Role in systemic acquired resistance. Plant Phys. 1997, 114, $1443-1451$. [CrossRef]

26. Huang, H.C.; Schuurink, R.; Denny, T.P.; Atkinson, M.M.; Baker, C.J.; Yucel, I.; Hutcheson, S.W.; Collmer, A. Molecular cloning of a Pseudomonas syringae pv. syringae gene cluster that enables Pseudomonas fluorescens to elicit the hypersensitive response in tobacco plants. J. Bacteriol. 1988, 170, 4748-4756. [CrossRef]

27. Cuppels, D.A. Generation and characterization of Tn5 insertion mutations in Pseudomonas syringae pv. tomato. Appl. Environ. Microbiol. 1986, 51, 323-327. [CrossRef] [PubMed]

28. Barna, B.; Gémes, K.; Domoki, M.; Bernula, D.; Ferenc, G.; Bálint, B.; Nagy, I.; Fehér, A. Arabidopsis NAP-related proteins (NRPs) contribute to the coordination of plant growth, developmental rate, and age-related pathogen resistance under short days. Plant Sci. 2018, 267, 124-134. [CrossRef] 
29. Buttner, P.; Koch, F.; Voigt, K.; Quidde, T.; Risch, S.; Blaich, R.; Bruckner, B.; Tudzynski, P. Variations in ploidy among isolates of Botrytis cinerea: Implications for genetic and molecular analyses. Curr. Genet. 1994, 25, 445-450. [CrossRef] [PubMed]

30. Barna, B.; Ádám, A.; Király, Z. Juvenility and resistance of a superoxide-tolerant plant to disease and other stresses. Naturwissenshaften 1993, 80, 420-422. [CrossRef]

31. Ritchie, M.E.; Silver, J.; Oshlack, A.; Silver, J.; Holmes, M.; Diyagama, D.; Holloway, A.; Smyth, G.K. A comparison of background correction methods for two-colour microarrays. Bioinformatics 2007, 23, 2700-2707. [CrossRef] [PubMed]

32. Yang, Y.H.; Dudoit, S.; Luu, P.; Speed, T.P. Normalization for cDNA microarray data. In Microarrays: Optical Technologies and Informatics; Bittner, M.L., Chen, Y., Dorsel, A.N., Dougherty, E.R., Eds.; SPIE, Society for Optical Engineering: San Jose, CA, USA, 2001; Volume 4266, pp. 141-152.

33. Yang, Y.H.; Dudoit, S.; Luu, P.; Lin, D.M.; Peng, V.; Ngai, J.; Speed, T.P. Normalization for cDNA microarray data: A robust composite method addressing single and multiple slide systematic variation. Nucleic Acids Res. 2002, 30, e15. [CrossRef]

34. Smyth, G.K.; Speed, T.P. Normalization of cDNA microarray data. Methods 2003, 31, 265-273. [CrossRef]

35. Yang, Y.H.; Thorne, N.P. Normalization for two-color cDNA microarray data. In Science and Statistics: A Festschrift for Terry Speed, IMS Lecture Notes-Monograph Series; Goldstein, D.R., Ed.; Institute of Mathematical Statistics: Durham, NC, USA, 2003; Volume 40, pp. 403-418. [CrossRef]

36. Du, Z.; Zhou, X.; Ling, Y.; Zhang, Z.; Su, Z. agriGO: A GO analysis toolkit for the agricultural community. Nucleic Acids Res. 2010, 38, W64-W70. [CrossRef]

37. Usadel, B.; Nagel, A.; Thimm, O.; Redestig, H.; Blaesing, O.E.; Palacios-Rojas, N.; Selbig, J.; Hannemann, J.; Piques, M.C.; Steinhauser, D.; et al. Extension of the visualization tool MapMan to allow statistical analysis of arrays, display of corresponding genes, and comparison with known responses. Plant Physiol. 2005, 138, 1195-1204. [CrossRef]

38. Smalle, J.; Kurepa, J.; Yang, P.; Babiychuk, E.; Kushnir, S.; Durski, A.; Vierstra, R.D. Cytokinin growth responses in Arabidopsis involve the 26S proteasome subunit RPN12. Plant Cell 2002, 14, 17-32. [CrossRef]

39. Kieber, J.J.; Schaller, G.E. Cytokinins. Arab. Book 2014, 12, e0168. [CrossRef]

40. Panda, B.B.; Sekhar, S.; Dash, S.K.; Behera, L.; Shaw, B.P. Biochemical and molecular characterisation of exogenous cytokinin application on grain filling in rice. BMC Plant Biol. 2018, 8, 89. [CrossRef] [PubMed]

41. Zuñiga-Mayo, V.M.; Baños-Bayardo, C.R.; Díaz-Ramírez, D.; Marsch-Martínez, N.; de Folter, S. Conserved and novel responses to cytokinin treatments during flower and fruit development in Brassica napus and Arabidopsis thaliana. Sci. Rep. 2018, 8, 6836. [CrossRef]

42. Mukherjee, D.; Kumar, R. Kinetin regulates plant growth and biochemical changes during maturation and senescence of leaves, flowers and pods of Cajanus cajan L. Biol. Plant. 2007, 51, 80-85. [CrossRef]

43. Babosha, A. Regulation of resistance and susceptibility in wheat-powdery mildew pathosystem with exogenous cytokinins. J. Plant Physiol. 2009, 166, 1892-1903. [CrossRef] [PubMed]

44. Stolz, A.; Riefler, M.; Lomin, S.N.; Achazi, K.; Romanov, G.A.; Schmülling, T. The specificity of cytokinin signalling in Arabidopsis thaliana is mediated by differing ligand affinities and expression profiles of the receptors. Plant J. 2011, 67, 157-168. [CrossRef] [PubMed]

45. Zwack, P.J.; Rashotte, A.M. Interactions between cytokinin signalling and abiotic stress responses. J. Exp. Bot. 2015, 66, 4863-4871. [CrossRef] [PubMed]

46. Rulcová, J.; Pospíšilová, J. Effect of benzylaminopurine on rehydration of bean plants after water stress. Biol. Plant. 2001, 44, 75-81. [CrossRef]

47. Sarwat, M.I.; El-Sherif, M.H. Increasing salt tolerance in some barley genotypes (Hordeum vulgare) by using kinetin and benzyladenine. World J. Agric. Sci. 2007, 3, 617-629.

48. O’Brien, J.A.; Benková, E. Cytokinin cross talking during biotic and abiotic stress responses. Front. Plant Sci. $2013,4,451$. [CrossRef]

49. Huang, X.; Hou, L.; Meng, J.; You, H.; Li, Z.; Gong, Z.; Yang, S.; Shi, Y. The antagonistic action of abscisic acid and cytokinin signaling mediates drought stress response in Arabidopsis. Mol. Plant. 2018, 11, 970-982. [CrossRef]

50. Nakashima, K.; Ito, Y.; Yamaguchi-Shinozaki, K. Transcriptional regulatory networks in response to abiotic stresses in Arabidopsis and grasses. Plant Physiol. 2009, 149, 88-95. [CrossRef]

51. Roychoudhury, A.; Paul, S.; Basu, S. Cross-talk between abscisic acid-dependent and abscisic acid-independent pathways during abiotic stress. Plant Cell Rep. 2013, 32, 985-1006. [CrossRef]

52. Kudo, M.; Kidokoro, S.; Yoshida, T.; Mizoi, J.; Kojima, M.; Takebayashi, Y.; Sakakibara, H.; Fernie, A.R.; Shinozaki, K.; YamaguchiShinozaki, K. A gene-stacking approach to overcome the trade-off between drought stress tolerance and growth in Arabidopsis. Plant J. 2019, 97, 240-256. [CrossRef] [PubMed]

53. Bari, R.; Jones, J.D.G. Role of plant hormones in plant defence responses. Plant Mol. Biol. 2009, 69, 473-488. [CrossRef]

54. Walters, D.R.; McRoberts, N. Plants and biotrophs: A pivotal role for cytokinins? Trends Plant Sci. 2006, 11, 581-586. [CrossRef]

55. Zhou, J.M.; Zhang, Y. Plant Immunity: Danger Perception and Signaling. Cell 2020, 181, 978-989. [CrossRef] [PubMed]

56. Nishad, R.; Ahmed, T.; Rahman, V.J.; Kareem, A. Modulation of plant defense system in response to microbial interactions. Front. Microbiol. 2020, 11, 1298. [CrossRef] [PubMed]

57. Balint-Kurti, P. The plant hypersensitive response: Concepts, control and consequences. Mol. Plant Pathol. 2019, 20, 1163-1178. [CrossRef] 
58. Künstler, A.; Bacso, R.; Albert, R.; Barna, B.; Király, Z.; Hafez, Y.; Fodor, J.; Schwarczinger, I.; Király, L. Superoxide (O⿰氵 $\left.{ }^{-}{ }^{-}\right)$ accumulation contributes to symptomless (type I) nonhost resistance of plants to biotrophic pathogens. Plant Physiol. Biochem. 2018, 128, 115-125. [CrossRef]

59. Bolduc, N.; Lamb, G.N.; Cessna, S.G.; Brisson, L.F. Modulation of Bax Inhibitor-1 and cytosolic Ca ${ }^{2+}$ by cytokinins in Nicotiana tabacum cells. Biochimie 2007, 89, 961-971. [CrossRef]

60. Kučerová, Z.; Rác, M.; Mikulík, J.; Plíhal, O.; Pospíšil, P.; Bryksová, M.; Sedlářová, M.; Doležal, K.; Špundová, M. The antisenescence activity of cytokinin arabinosides in wheat and Arabidopsis is negatively correlated with ethylene production. Int. J. Mol. Sci. 2020, 21, 8109. [CrossRef] [PubMed]

61. Liu, Y.; Zhang, M.; Meng, Z.; Wang, B.; Chen, M. Research progress on the roles of cytokinin in plant response to stress. Int. J. Mol. Sci. 2020, 21, 6574. [CrossRef] [PubMed]

62. Thompson, J.E.; Froese, C.D.; Madey, E.; Smith, M.D.; Hong, Y. Lipid metabolism during plant senescence. Prog. Lipid Res. 1998, 37, 119-141. [CrossRef]

63. Barna, B.; Pogány, M. Antioxidant enzymes and membrane lipid composition of disease resistant tomato plants regenerated from crown galls. Acta Physiol. Plant. 2001, 23, 273-277. [CrossRef]

64. Deák, M.; Horváth, G.V.; Davletova, S.; Török, K.; Sass, L.; Vass, I.; Barna, B.; Király, Z.; Dudits, D. Plants ectopically expressing the iron-binding protein, ferritin, are tolerant to oxidative damage and pathogens. Nat. Biotechnol. 1999, 17, 192-198. [CrossRef]

65. Brenner, W.G.; Ramireddy, E.; Heyl, A.; Schmülling, T. Gene regulation by cytokinin in Arabidopsis. Front. Plant Sci. 2012, 3, 8. [CrossRef] [PubMed]

66. Rashotte, A.M.; Carson, S.D.; To, J.P.; Kieber, J.J. Expression profiling of cytokinin action in Arabidopsis. Plant Physiol. 2003, 132, 1998-2011. [CrossRef]

67. Brenner, W.G.; Schmülling, T. Summarizing and exploring data of a decade of cytokinin-related transcriptomics. Front. Plant Sci. 2015, 6, 29. [CrossRef] [PubMed]

68. Bhargava, A.; Clabaugh, I.; To, J.P.; Maxwell, B.B.; Chiang, Y.H.; Schaller, G.E.; Loraine, A.; Kieber, J.J. Identification of Cytokinin Responsive Genes Using Microarray Meta-analysis and RNA-Seq in Arabidopsis. Plant Physiol. 2013, 162, 272-294. [CrossRef] [PubMed]

69. Bozsó, Z.; Maunoury, N.; Szatmári, Á.; Mergaert, P.; Ott, P.G.; Zsíros, L.R.; Szabó, E.; Kondorosi, E.; Klement, Z. Transcriptome analysis of bacterially induced basal and hypersensitive response of Medicago truncatula. Plant. Mol. Biol. 2009, 70, 627-646. [CrossRef]

70. Bozsó, Z.; Ott, P.G.; Kámán-Tóth, E.; Bognár, G.F.; Pogány, M.; Szatmári, Á. Overlapping yet response-specific transcriptome alterations characterize the nature of tobacco-Pseudomonas syringae interactions. Front. Plant Sci. 2016, 7, 251. [CrossRef] 